NBER WORKING PAPER SERIES

\title{
EFFECTS OF SPECULATION AND INTEREST RATES IN A "CARRY TRADE" MODEL OF COMMODITY PRICES
}

\author{
Jeffrey A. Frankel \\ Working Paper 19463 \\ http://www.nber.org/papers/w19463 \\ NATIONAL BUREAU OF ECONOMIC RESEARCH \\ 1050 Massachusetts Avenue \\ Cambridge, MA 02138 \\ September 2013
}

The paper was originally written for Understanding International Commodity Price Fluctuations, an International Conference organized by Rabah Arezki and sponsored by the IMF's Research Department and the Oxford Centre for the Analysis of Resource Rich Economies at Oxford University, held March 20-21, 2013, Washington, D.C. The author would like to thank Marco Antonio Martinez del Angel for invaluable research assistance, the Weatherhead Center for International Affairs and the Smith Richardson Foundation for support, and Lutz Kilian for data, Philip Hubbard for conversations regarding the Consensus Economics forecast data; and to thank for comments Rabah Arezki, James Hamilton, Scott Irwin, Lutz Kilian, Will Martin, and three anonymous referees. The views expressed herein are those of the author and do not necessarily reflect the views of the National Bureau of Economic Research.

NBER working papers are circulated for discussion and comment purposes. They have not been peerreviewed or been subject to the review by the NBER Board of Directors that accompanies official NBER publications.

(C) 2013 by Jeffrey A. Frankel. All rights reserved. Short sections of text, not to exceed two paragraphs, may be quoted without explicit permission provided that full credit, including $\mathbb{C}$ notice, is given to the source. 
Effects of Speculation and Interest Rates in a "Carry Trade" Model of Commodity Prices

Jeffrey A. Frankel

NBER Working Paper No. 19463

September 2013, Revised January 2014

JEL No. Q11,Q39

\begin{abstract}
$\underline{\text { ABSTRACT }}$
The paper presents and estimates a model of the prices of oil and other storable commodities, a model that can be characterized as reflecting the carry trade. It focuses on speculative factors, here defined as the trade-off between interest rates on the one hand and market participants' expectations of future price changes on the other hand. It goes beyond past research by bringing to bear new data sources: survey data to measure expectations of future changes in commodity prices and options data to measure perceptions of risk. Some evidence is found of a negative effect of interest rates on the demand for inventories and thereby on commodity prices and positive effects of expected future price gains on inventory demand and thereby on today's commodity prices.
\end{abstract}

Jeffrey A. Frankel

Harvard Kennedy School

Harvard University

79 JFK Street

Cambridge, MA 02138

and NBER

jeffrey_frankel@harvard.edu 


\section{Effects of Speculation and Interest Rates in a "Carry Trade" Model of Commodity Prices}

This paper presents and attempts to estimate a model of macroeconomic determinants of prices of oil and other commodities, with an emphasis on the intermediating role of inventories. It could be called the "carry trade" model in the light it shines on the trade-off between interest rates and speculation regarding future changes in the price of the commodity. Low real US interest rates are a signal that money is plentiful, with the result that funds venture far afield in search of higher expected returns, whether it is in mineral commodities or in foreign currencies.

The phrase "carry trade" is today primarily associated with speculation in international fixed-income markets, where the spot price of concern is the price of foreign exchange and the "cost of carry" is the international difference in interest rates. There is perhaps an irony here, because the original intuition comes from more tangible commodities, where the cost of carry includes storage costs (among other variables).

\section{Macroeconomic Influences}

There are times when so many commodity prices move so much together that it becomes difficult to ignore the influence of macroeconomic phenomena. The decade of the 1970s was one such time. Recent history provides another. It cannot be a coincidence that prices of oil and almost all mineral and agricultural commodity prices rose in unison from 2001 to 2007, peaked jointly and abruptly in mid-2008, plunged together in 2009, and attained together a second peak in 2011. Three theories compete to explain increases in commodity prices in recent years.

First, and perhaps most standard, is the global growth explanation. This argument stems from the unusually widespread growth in economic activity after 2000 - particularly including the arrival of China and other entrants to the list of important economies and their rapid recovery 
from the 2008-09 global recession - together with the prospects of continued high growth in those countries in the future. This growth has raised the demand for, and hence the price of, commodities. (See Kilian and Hicks, 2012.)

The second explanation -- also highly popular, at least among the public -- is speculation. Many commodities are highly storable; a large number are actively traded on futures markets. We can define speculation as the purchases of the commodities, whether in physical form or via contracts traded on an exchange, in anticipation of financial gain at the time of resale. This includes not only the possibility of destabilizing speculation (bandwagon effects), which is what the public often has in mind, but also the possibility of stabilizing speculation. The latter case is the phenomenon whereby a rise in the spot price relative to its long run equilibrium generates expectations of a price decline in the future, leading market participants to sell or short the commodity today and thereby dampen the price increase today.

One kind of evidence that has been brought to bear on this argument is the behaviour of inventories. Krugman (2008a, b) and Wolf (2008), for example, argued that inventories were not historically high at the time of the 2008 price spike and therefore that speculators could not have been betting on price increases and could not have added to the current demand. Others have found evidence in inventory data that they interpret as consistent with an important role for speculation, driven for example by geopolitical fears of disruption to the supply of Mideastern oil. (See Kilian and Murphy, 2013; Kilian and Lee, 2013).

The third explanation is that easy monetary policy has contributed to increases in commodity prices, via either high demand or low supply. Easy monetary policy often shows up as low real interest rates. ${ }^{1}$ Barsky and Kilian $(2002,2004)$ and others have argued that high

\footnotetext{
${ }^{1}$ See Frankel (2008a, b), for example.
} 
prices for oil and other commodities in the 1970s were not exogenous, but rather a result of easy monetary policy. The same could be argued for other mineral and agricultural commodities. Conversely, a substantial increase in real interest rates drove commodity prices down in the early 1980s, especially in the United States. High real interest rates raise the cost of holding inventories. Lower demand for inventories then contributes to lower total demand for commodities. $^{2}$

After 2000, the process went into reverse. The Federal Reserve cut real interest rates sharply in 2001-2004, and again in 2008-2011. Each time, it lowered the cost of holding inventories thereby contributing to an increase in demand. The analogy with the carry trade in foreign exchange is clear: low interest rates send investors far afield in their search for yield, whether it is into commodities or foreign assets.

As a preliminary illustration of the possible monetary influence on commodity markets, Figure 1a shows the time series for real interest rates from 1950 to 2012 together with a time series for the real value of a commodity price index (Moody's Commodity price index, deflated). The advantage of looking at an aggregate index, as opposed to prices of individual commodities, is that the host of idiosyncratic factors that influence each individual sector may wash out. Commodity price spikes in the 1970s, 2008 and 2011 coincide with real interest rates that are zero or even negative. Figure $1 \mathrm{~b}$ presents the same data in the form of a plot, with the real interest rate on the horizontal axis and the real commodity price on the vertical axis. A negative correlation is visible.

\footnotetext{
${ }^{2}$ A second effect of higher interest rates is that they undermine the incentive for oil-producing countries to keep crude oil under the ground. By pumping oil instead of preserving it, OPEC countries could invest the proceeds at interest rates that were higher than the return to leaving it in the ground. Higher rates of pumping increase supply; both lower demand and higher supply contribute to a fall in oil prices. The same mechanisms apply to decisions about extracting minerals, logging forests, harvesting crops, etc.
} 
Figure 1a: Real commodity price index (Moody's) and real interest rates; time series

When monetary policy is easy, real commodity prices tend to be high 1950-2012



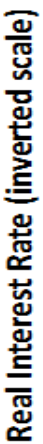

Figure 1b: Real commodity price index (Moody's) and real interest rates; plot

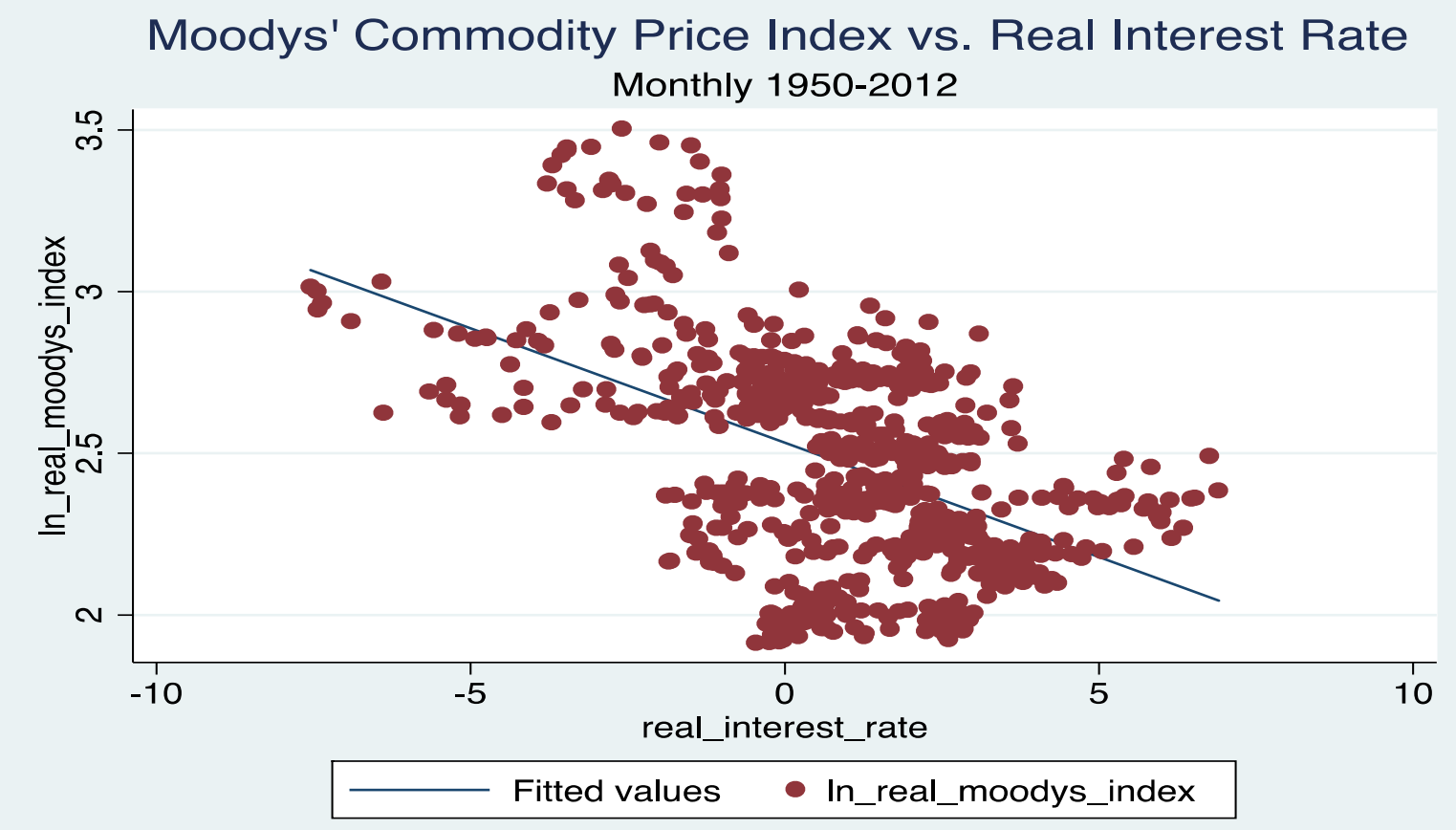


Critics of the interest rate theory as an explanation of increased prices for oil and other commodities over the last decade have pointed out that it implies that inventory levels should have been high and have argued that they were not (e.g., Kohn, 2008). This is the same missing link that has been raised in objection to the destabilising speculation theory. For that matter, the missing inventories link objection can be applied to most theories. ${ }^{3}$ Explanation number one, the global boom story, is often phrased in terms of expectations of future growth rates, not just a currently-high income levels; but this factor, too, if operating in the marketplace, should in theory work to raise demand for inventories.

The price spike in 2008 worked in favour of explanations number two and three, the speculation and interest rate theories, at the expense of explanation number one, the global boom. Previously, rising demand from the global expansion, especially the boom in China, had seemed the obvious explanation for rising commodity prices. But the sub-prime mortgage crisis hit the United States around August 2007. Virtually every month thereafter, forecasts of growth were downgraded, not just for the United States but for the rest of the world as well, including China. ${ }^{4}$ Meanwhile commodity prices, far from declining as one might expect from the global demand hypothesis, climbed at an accelerated rate. For the year following August 2007, at least, the global boom theory did not seem as relevant. That left explanations number two and three. Of course the 2008 spike represents just one data point. ${ }^{5}$

This paper presents a model of the prices of oil and other storable commodities, which can be characterized as reflecting the carry trade. It then attempts econometric estimation of the model. It focuses on speculative factors, here defined as the trade-off between interest rates on

\footnotetext{
${ }^{3}$ I am indebted to Larry Summers for this point.

${ }^{4}$ For example, World Economic Outlook, International Monetary Fund, October 2007, April 2008 and October 2008. Also OECD and World Bank. For the opposing viewpoint, see Kilian and Hicks (2012).

${ }^{5}$ Frankel (2008b) and Hamilton (2008, 2009).
} 
the one hand and market participants' expectations of future price changes on the other hand. Inventories are a mediating variable between these factors and commodity prices. Data on inventories are readily available in the case of oil, and to a lesser extent for some other commodities.

Previous attempts to estimate the role of oil inventories in mediating speculation ${ }^{6}$ have not had the benefit of an explicit measure of expectations held by market participants; they thus have had to infer the speculative factor implicitly rather than measuring it explicitly. This paper attempts to capture the speculative factor explicitly by using data on forecasts of future commodity prices from a survey of market participants. Furthermore, where past attempts to capture the role of risk have usually relied on actual volatility measures, this paper also uses the subjective measure of volatility implicit in options prices. This measure can incorporate sudden changes in the uncertainty of world commodity markets in a way that a backward-looking measure like lagged actual volatility cannot.

To preview the main findings: there is some empirical support for the hypothesized roles of inventories, economic activity, and - most importantly - the two determinants of the carry trade: interest rates and expected future commodity price changes. The results suffer from a number of limitations, however; much remains to be done.

\section{A Carry-Trade Theory of Commodity Price Determination}

Most fossil fuels, minerals, and agricultural commodities differ from other goods and services in that they are both storable and relatively homogeneous. As a result, they are hybrids

\footnotetext{
${ }^{6}$ E.g., Kilian and Murphy (2013), Kilian and Lee (2013), Frankel (2008, Table 2) and Frankel and Rose, 2010),
} 
of assets - where price is determined by supply of and demand for stocks - and goods, for which the flows of supply and demand matter.

The elements of an appropriate model have long been known. ${ }^{7}$ The monetary aspect of the theory can be reduced to its simplest algebraic essence as a relationship between the real interest rate and the spot price of a commodity relative to its expected long-run equilibrium price. This relationship can be derived from two simple assumptions. The first governs expectations. Let:

$s \equiv$ the natural logarithm of the spot price, $p \equiv$ the (log of the) economy-wide price index, $q \equiv s-p$, the $(\log )$ real price of the commodity, and $\bar{q} \equiv$ the long run (log) equilibrium real price of the commodity.

Market participants who observe the real price of the commodity today lying either above or below its perceived long-run equilibrium value, expect it to return back to equilibrium in the future over time, at an annual rate that is proportionate to the gap:

$$
\begin{array}{ll} 
& E[\Delta(s-p)] \equiv E[\Delta q]=-\theta(q-\bar{q}) \\
\text { or } \quad & E(\Delta s)=-\theta(q-\bar{q})+E(\Delta p) .
\end{array}
$$

For present purposes, it may be enough simply to assert that this is a reasonable form for expectations to take: It seems reasonable to expect a tendency for the price of a commodity to

\footnotetext{
${ }^{7}$ See Frankel (1986, 2008a) and Frankel and Hardouvelis (1985). The classic Dornbusch (1976) overshooting paper developed the model for the case of exchange rates. The commodities version of the overshooting model essentially substituted the price of commodities for the price of foreign exchange and substituted convenience yield (adjusted for storage costs) for the foreign interest rate. A popular alternative approach is the competitive storage model of Deaton and Laroque (1996).
} 
regress back toward long run equilibrium in the future. But it can be shown that regressive expectations are also rational expectations, under certain assumptions regarding the stickiness of prices of other goods (manufactures and services) and a certain restriction on the parameter value $\theta$.

The next equation concerns the decision whether to hold commodity inventories for another period or to sell at today's price and use the proceeds to earn interest. The expected rate of return to these two alternatives should be equalized:

$$
E(\Delta s)+c=i, \quad \text { where: } c \equiv c y-s c+r p
$$

$i \equiv$ the nominal interest rate;

$c y \equiv$ convenience yield from holding the stock (for example, the insurance value of having an assured supply of some critical input in the event of a disruption or, in the case of a commodity like gold, the psychic pleasure of holding it); $s c \equiv$ storage costs (for example, feed lot rates for cattle, silo rents and spoilage rates for grains, rental rates on oil tanks or oil tankers, costs of security to prevent plundering by others, etc. $){ }^{8}$ $r p \equiv(f-s)-E(\Delta s) \equiv$ risk premium, where $f$ is the log of the forward/futures rate at the same maturity as the interest rate. The risk premium (when defined in this way, which is from the point of view of the hedger) should be negative if being long in commodities is risky, requiring compensation to those who expose themselves to the risk, but should be positive if commodities offer a natural hedging opportunity because their prices are negatively correlated with the market return on the aggregate asset

\footnotetext{
${ }^{8}$ Fama and French (1987) and Bopp and Lady (1991) emphasise storage costs.
} 
portfolio. Hamilton (2013) and Hamilton and $\mathrm{Wu}$ (2013) suggest that financialization, the widely noted phenomenon of hedge funds and other investors in recent years entering the commodity markets on the long side via index funds, is reflected in the diminution of the risk premium since $2005 .^{9}$

$(f-s)=$ The Futures-Spot Spread. If one is interested in the derivatives markets, one often focuses on the forward discount or slope of the futures curve, $f-s$ in log terms (also sometimes called the "spread" or the "roll"). The spread $f-s$ is often negative. This phenomenon, "backwardation," suggests that convenience yield outweighs the interest rate and storage costs; it may signal that inventories are running low at a particular point in time, so the market is "tight" and pays a premium for prompt delivery. Keynes (1930) thought that backwardation would be the "normal" state, because farmers wishing to hedge their crops would have to pay a premium to those willing to take the other side of the transaction; this risk premium would in turn imply a negative spread if the expected future rate is close or equal to today's spot rate (as in a random walk). ${ }^{10}$ But sometimes $f$-s is positive, which is called "contango," signalling that the market is soft, because inventories are plentiful.

The null hypothesis that the forward spread is an unbiased forecast of the future change in the spot price has been tested extensively. ${ }^{11}$ This issue does not affect the questions addressed

\footnotetext{
${ }^{9}$ Working (1949) and Breeden (1980) are classic references on the roles of carrying costs and the risk premium, respectively, in commodity markets. Yang, Bessler and Leatham (2001) review the literature.

${ }^{11}$ For example, Kolb (1992).

${ }^{11}$ E.g., Alquist and Kilian (2010), Alquist, Kilian and Vigfusson (2011) and the Appendix to Frankel and Rose (2009). As in the (more extensive) tests of the analogous unbiasedness propositions in the contexts of forward foreign exchange markets and the term structure of interest rates, the null hypothesis is usually rejected: the carry trade on average makes money. The common finding is that the current spot price is a better predictor of the future spot price than is the futures or forward rate.
} 
in this paper, however. Here we nte only that one need not necessarily interpret the finding of bias in the futures rate as a rejection of rational expectations; it could be due to a risk premium. As just defined, the risk premium $r p$ is the difference between the spread $(f-s)$ and the expected increase in the commodity price. To get our main result, we simply combine Equations (2) and (3):

$$
\begin{aligned}
& -\theta(q-\bar{q})+E(\Delta p)+c=i \\
& \Rightarrow q-\bar{q}=-(1 / \theta)(i-E(\Delta p)-c) .
\end{aligned}
$$

Equation (4) says that the real price of the commodity, measured relative to its long-run equilibrium, is inversely proportional to the real interest rate (measured relative to the term $c$, which could be described as the net convenience yield - that is, the convenience yield after accounting for storage costs and any risk premium). When the real interest rate rises, as in the early 1980s, money will flow out of commodities and prices will fall. This will continue until the prices of commodities are perceived to lie sufficiently below their future equilibria, generating expectations of future price increases, at which point the quasi-arbitrage or carry-trade condition will be met. Conversely, when the real interest rate is reduced, as in 2001-05 and 2008-12, money will flow into commodities and prices will rise. This will continue until the prices of commodities are perceived to lie sufficiently above their future equilibria, generating expectations of future price decreases, so as to satisfy the carry-trade condition. This is the overshooting model.

If the net convenience yield, $c$, could be treated as constant, equation (4) would give us a simple correlation between the real interest rate, $r$, and real commodity price, $q$, of the sort sketched in Figures 1a and 1b. To measure how strong is the inverse relationship that the eye 
observes, Table 1 presents a bivariate regression of the commodity price indices (in real terms) against the real interest rate (computed very simply with lagged inflation). The relationship is highly significant statistically, regardless which of four standard indices of commodity prices is used. When the dependent variable is the Moody's commodity price index, the estimated coefficient suggests that every 100 basis point increase in the real interest rate lowers real commodity prices by 7 per cent. Similar results hold for the indices calculated by CRB, Dow Jones, and Goldman Sachs.

Table 1: Regression of real commodity price indices against real interest rate (1950-2012) Dependent variable: log of commodity price index, deflated by US CPI

\begin{tabular}{|c|c|c|c|c|}
\hline VARIABLES & $\begin{array}{l}\text { CRB } \\
\text { index }\end{array}$ & $\begin{array}{l}\text { Dow Jones } \\
\text { Index }\end{array}$ & $\begin{array}{l}\text { Moody's } \\
\text { index }\end{array}$ & $\begin{array}{c}\text { Goldman Sachs } \\
\text { Index }\end{array}$ \\
\hline \multirow[t]{2}{*}{ Real interest rate } & $-0.041 * * *$ & $-0.034 * * *$ & $-0.071 * * *$ & $-0.075 * * *$ \\
\hline & $(0.007)$ & $(0.006)$ & $(0.005)$ & $(0.007)$ \\
\hline \multirow[t]{2}{*}{ Constant } & $0.900 * * *$ & $0.066 * * *$ & $2.533^{* * *}$ & $0.732 * * *$ \\
\hline & (0.017) & $(0.016)$ & (0.011) & $(0.018)$ \\
\hline Observations & 739 & 739 & 739 & 513 \\
\hline \multirow[t]{2}{*}{ R2 } & 0.04 & 0.04 & 0.25 & 0.18 \\
\hline & & 01 & & \\
\hline
\end{tabular}

INFLATION (Month X, Year T) =Log CPI (Month X, Year T) - Log CPI (Month X, Year T-1)

REAL INTEREST RATE (Month X, YEAR T) = [3-TBILL(Month X, YEAR T)/100 - INFLATION (Month X-1, YEAR T) ]*100 for months (Feb-Dec) ;

for Jan we take INFLATION (Month X-1, YEAR T-1). Source for 3-month treasury bill rates: Federal Reserve Bank of St. Louis

Table 1 thus offers preliminary support for the negative relationship between the real interest rate and real commodity prices of Equation (4). But of course correlation need not imply causality. Furthermore, there is no reason for the net convenience yield, $c$, in Equation (4) to be constant. Important factors were left out of the equation estimated in Table 1. 
Substituting from (3) into (4),

$$
\begin{aligned}
& c \equiv c y-s c+r p=> \\
& q-\bar{q}=-(1 / \theta)[i-E(\Delta p)-c y+s c-r p] \\
& q=\bar{q}-(1 / \theta)[i-E(\Delta p)]+(1 / \theta) c y-(1 / \theta) s c+(1 / \theta) r p .
\end{aligned}
$$

Thus, even if we continue to take the long-run equilibrium $\bar{q}$ as given by a constant or a trend, there are other variables in addition to the real interest rate that determine the real price: the convenience yield, storage costs, and the risk premium. Furthermore the long-run equilibrium real commodity price $\bar{q}$ need not necessarily be constant. Fluctuations in the convenience yield, storage costs, or the risk premium might also contain a permanent component; all such effects would then appear in the equation. ${ }^{12}$

To translate Equation (5) into empirically usable form, there are several measurable determinants of the real commodity price for which we need to account. We discuss these in turn.

Inventories. How can costs of storage be measured? Storage costs rise with the extent to which inventory holdings strain existing storage capacity: $s c=\Phi$ (INVENTORIES). If the level of inventories is observed to be at the high end historically, then storage costs must be high, absent

\footnotetext{
${ }^{12}$ An additional hypothesis of interest is that storable commodities may serve as a hedge against inflation. Under this view, an increase in the expected long-run inflation rate would then raise the demand for commodities thereby increasing real commodity prices today. (E.g., Calvo, 2008.)
} 
any large recent increase in storage capacity. This should have a negative effect on commodity prices. ${ }^{13}$ Substituting into Equation (5),

$$
q=\bar{q}-(1 / \theta) \Phi(\text { INVENTORIES })-(1 / \theta)[i-E(\Delta p)]+(1 / \theta) c y+(1 / \theta) r p .
$$

The next section of the paper will estimate an equation for the determination of inventory holdings, a central building block of the price model. The equation can be derived as follows: From Equation (3),

$$
\begin{aligned}
& E(\Delta s)+c y-s c+r p=i \\
& \text { or } s c=[E(\Delta s)-i]+c y+r p .
\end{aligned}
$$

Combine equation (7) with the inverted form of the relationship between the marginal cost of storage and the quantity of the commodity in storage:

$$
\begin{aligned}
\text { INVENTORIES }= & \Phi^{-1}\{s c\} \\
& =\Phi^{-1}\{[E(\Delta s)-i]+c y+r p\}
\end{aligned}
$$

We see that low interest rates should predict not only high commodity prices but also high inventory holdings (other things equal). High expectations of future price increases should also be associated with high inventories. ${ }^{14}$

There is no reason to think that the relationship $\Phi($ ) is necessarily linear. We assume linearity in our estimation for simplicity, but allowing for non-linearity is a desirable extension

\footnotetext{
${ }^{13}$ Ye et al $(2002,2005,2006)$, for example, emphasise the role of inventories in forecasting oil prices.

${ }^{14}$ As in the arguments of Krugman (2008a,b), Kohn (2008) and Wolf (2008).
} 
of the analysis. Under the logic that inventories are bounded below by zero and above by some absolutely peak storage capacity, a logistic function might be appropriate.

An innovation of this paper concerns the measurement of expected future changes in spot commodity prices, $E(\Delta s)$. Previous econometric attempts to measure this key variable have generally used one of three approaches. (i) The rational expectations methodology substitutes observed ex post changes in the spot rate $(\Delta s)$, for the expectation $E(\Delta s)$, inverts the equation, and relies on the rational expectations proposition that the prediction error $(\Delta s)-E(\Delta s)$ should be uncorrelated with all variables observed at the time the expectation is formed. Even assuming one is willing to accept the rational expectations hypothesis (unbiased forecasts), we know that the prediction errors are huge (poor forecasts) because so much is not known ahead of time. The ex post realization is such an extremely noisy indicator of the ex ante expectation that its value in a regression to determine the supply and demand for commodities is questionable, especially in short samples.

(ii) The projection approach regresses price changes on observed macroeconomic variables, e.g., by a Vector Auto Regression, and then uses the fitted values to model expectations. The problem with this approach is that it is hard enough to find a good model of commodity prices ex post; a short list of variables recorded at the time expectations are formed is sure to leave out most of the relevant information that market participants use, such as recent news about political instability in supplier countries or about the macroeconomic outlook in consumer countries. The information set can change very quickly in commodity markets.

(iii) The inventory approach infers from firms' inventory behavior what price changes they must be expecting. The problem here is that, as our equation illustrates, inventory demand 
is determined by other factors in addition to price expectations: convenience yield and other variables, including in practice omitted factors that go into the regression error. To infer price expectations from inventory data would confound expectations with these other determinants.

The aforementioned innovation in this paper is that expected future changes in spot commodity prices, $\mathrm{E}(\Delta s)$, are measured by a survey of market participants conducted by Consensus Forecasts, collected from "over 30 of the world's most prominent commodity forecasters." It is important to acknowledge that this measure, too, faces objections. Alquist, Kilian, and Vigfusson (2011, Section 5.2.3) point out that the survey data are poor predictors of ex post outcomes $(\Delta s)$. To this objection can be offered three counter-arguments. First, all ex ante variables are poor predictors of ex post price changes, even the optimal ones. Second, the goal is to capture what market participants are thinking - regardless of whether their forecasts are accurate, inaccurate, biased, or unbiased - because their expectations determine their behaviour. Third, although the surveys could well be subject to measurement error, it should not be hard to improve on the large measurement errors of alternative measures of ex ante expectations such as ex post realizations.

Economic Activity (denoted $Y$ ) is a determinant of the convenience yield $c y$, since it drives the transactions demand for inventories. Higher economic activity should have a positive effect on the demand for inventory holdings and thus on prices. Let us designate the relationship $\gamma(Y)$. Again we assume linearity, somewhat arbitrarily. We usually measure this with GDP or industrial production. There is a good case for using a measure of global economic activity rather than US activity, especially in the price equation (or in an inventory equation using data for global inventories rather than US inventories alone). There are also grounds for thinking that the contemporaneous level of economic activity might not have a positive effect on inventories 
and indeed that an unexpectedly high level of economic activity might result in a temporary drawdown of stocks because firms had not set inventories in anticipation of the higher demand. In that case one might focus on the expected change in economic activity as the variable determining firms' decision whether to add to inventories relative to the previous level.

Risk or Volatility (denoted $\sigma$ ), can be measured either by actual observed price volatility or - an innovation in this paper - the subjective volatility that is implied by commodities options prices. ${ }^{15}$ The theoretical effect of risk is ambiguous. Risk is another determinant of $c y$, to the extent that risk concerns fear of disruption of availability, whereby it should have a positive effect on inventory demand and therefore on commodity prices. But it is also a determinant of the risk premium $r p$, whereby it could have a negative effect on commodity prices.

Substituting these extra effects into Equation (7), we get

$$
q=C-(1 / \theta) \Phi(\text { INVENTORIES })-(1 / \theta)[i-E(\Delta p)]+(1 / \theta) \gamma(Y)+(1 / \theta)([f-s-E(\Delta s)]) .
$$

It is this equation - augmented by what one hopes is a well-behaved residual term - that we wish to investigate.

Each of the variables on the right-hand side of Equation (9) could easily be considered endogenous. This must be considered a limitation of our analysis. We are short of plausibly exogenous variables with which to identify such equations. From the viewpoint of an individual commodity though, aggregate variables such as the real interest rate and GDP can reasonably be considered exogenous. ${ }^{16}$

\footnotetext{
${ }^{15}$ Frankel and Rose (2009) measured risk (political, financial and economic), in the case of oil, by a weighted average of political risk among 12 top oil producers.

${ }^{16}$ Also inventories could perhaps be considered pre-determined, since it takes time for firms to add to inventories.
} 


\section{Estimation of the Inventory Equation, for the Case of Oil}

We begin by estimating equation (8), which is intended to capture the determinants of inventories, a central building block of the model.

$$
\text { INVENTORIES }=\Phi^{-1}\{[E(\Delta s)-i]+c y+r p\}
$$

As throughout, we assume that convenience yield depends on a measure of economic activity and perhaps on a measure of risk. Unfortunately oil is the only commodity for which we have all the data necessary to estimate the inventory equation.

It is common for inventory variables to appear in equations for the prices of oil and other storable commodities. The intuition seems immediate: if inventories are thought of as a measure of supply: when oil is plentiful, prices are low; when shortages threaten, prices are high. But in our model, inventories are there to reflect storage costs in the carry trade or arbitrage relationship. One place where the distinction is important is the choice of measure of inventories. In an integrated world market, it might seem that one must use a measure of global inventories. Maybe, but not necessarily. In theory, the holdings of any well-defined sub-set of market participants are valid, if they reflect the storage costs (and price expectations, convenience yield, and interest rate) facing that sub-set of participants. In particular if the data on US crude oil inventories are better than available global data, it might be better to use them (along with the interest rate and convenience yield facing US firms). Yes, this leaves out the rapid growth in China's share of the oil market, for example. But it may actually be better to leave out China's inventory holdings. Even if the data were just as good as US data, it is likely that storage capacity has grown in China, indeed accelerated. Inventory holdings would be 
misleading if they were growing at the same rate as storage capacity, or less rapidly than storage capacity: it would give the signal that storage costs are rising rapidly when they may not be.

Thus we will estimate equations for both US inventories and global inventories, as alternative windows on the arbitrage condition in action. When we use US inventory holdings we should use a measure of US economic activity, in order to capture convenience yield for American firms. ${ }^{17}$ When we use global inventory holdings we need to use a measure of global economic activity.

We begin in Table 2 a with US inventories, where the numbers for crude oil are relatively reliable. The most important variable is the speculative term $[E(\Delta s)-i]$. Its coefficient is positive and statistically significant in seven incarnations of the inventory equation. The expectation of future price increases, relative to the interest rate, raises the desired inventory holdings. This finding is apparently a major pay-off from having applied the survey data to the analysis of speculation, in that it furnishes what some have considered a missing link (via inventories) in the theories that either easy monetary policy or speculation are responsible for some of the price variation over the last decade.

Growth in US industrial production has a highly significant effect on US inventory demand. Alternatively, expectations of future industrial production growth also have a positive effect. One can glean some support for the principle that firms set plans for a target level of inventories based on the expected level of economic activity and that an increase in economic

\footnotetext{
${ }^{17}$ We are implicitly considering inventories relative to full capacity, but explicit adjustment would improve the measurement, if the appropriate data on storage capacity could be found. We hope that the trend term adequately captures storage capacity. We tried expressing inventories relative to production, rather than in log form, but had little luck with this formulation.
} 
activity beyond what had been expected reduces actual inventory holdings: contemporaneous industrial production has a negative effect.

The second panel in Table 2a controls for lagged US inventories. Its coefficient is almost 0.8 , and highly significant, suggesting a speed of adjustment of just over 0.2 per year. Significance of other variables falls sharply, but the speculative term, [E( $\Delta s)-i]$, remains significant under all permutations. Its estimated short-run coefficient is in the range .034-.041. 


\section{Table 2a: US Inventory Equation}

Dependent Variable: Log U.S. Stocks Crude Oil Millions of barrels (1995-2011), quarterly observations $†$

Without lagged stocks

\begin{tabular}{|c|c|c|c|c|c|c|c|}
\hline VARIABLES & (1) & (2) & (3) & (4) & (5) & (6) & (7) \\
\hline $\begin{array}{l}\text { Forecast price rise } \\
\text { - nominal interest rate }\end{array}$ & $\begin{array}{l}0.055^{\star} \\
(0.030)\end{array}$ & $\begin{array}{l}0.103^{* * *} \\
(0.027)\end{array}$ & $\begin{array}{l}0.127^{* * *} \\
(0.030)\end{array}$ & $\begin{array}{c}0.084^{* * *} \\
(0.027)\end{array}$ & $\begin{array}{l}0.064^{* *} \\
(0.024)\end{array}$ & $\begin{array}{l}0.078^{* * *} \\
(0.027)\end{array}$ & $\begin{array}{l}0.048^{*} \\
(0.025)\end{array}$ \\
\hline $\begin{array}{l}\text { Log U.S. Industrial Production; } \\
\text { Index, } 2005=100 \text {, Seasonally Adjusted }\end{array}$ & $\begin{array}{l}-0.233^{* * *} \\
(0.074)\end{array}$ & & & & $\begin{array}{l}-0.230^{* * *} \\
(0.079)\end{array}$ & $\begin{array}{l}-0.264^{* * *} \\
(0.076)\end{array}$ & $\begin{array}{l}-0.223^{* \star *} \\
(0.081)\end{array}$ \\
\hline Actual IP growth & & $\begin{array}{l}0.320^{* *} \\
(0.128)\end{array}$ & & $\begin{array}{l}0.579^{\star \star \star} \\
(0.191)\end{array}$ & $\begin{array}{l}0.359^{* * *} \\
(0.116)\end{array}$ & & $\begin{array}{l}0.591^{* * *} \\
(0.183)\end{array}$ \\
\hline $\begin{array}{l}\text { Forecast rate of change of } \\
\text { U.S. IP, at two-year horizon }\end{array}$ & & & $\begin{array}{l}0.462^{*} \\
(0.243)\end{array}$ & $\begin{array}{l}-0.569 \\
(0.346)\end{array}$ & & $\begin{array}{l}0.537^{* *} \\
(0.213)\end{array}$ & $\begin{array}{l}-0.512 \\
(0.342)\end{array}$ \\
\hline Annual trend times 100 & $\begin{array}{c}0.449^{* * *} \\
(0.028)\end{array}$ & $\begin{array}{c}0.417^{* * *} \\
(0.025)\end{array}$ & $\begin{array}{c}0.375^{* * *} \\
(0.021)\end{array}$ & $\begin{array}{c}0.437^{* * *} \\
(0.026)\end{array}$ & $\begin{array}{l}0.493^{* * *} \\
(0.036)\end{array}$ & $\begin{array}{l}0.466^{* * *} \\
(0.034)\end{array}$ & $\begin{array}{l}0.508^{* * *} \\
(0.035)\end{array}$ \\
\hline Constant & $\begin{array}{c}7.772^{\star \star \star} \\
(0.324)\end{array}$ & $\begin{array}{c}6.723^{\star \star \star} \\
(0.012)\end{array}$ & $\begin{array}{c}6.736^{\star \star \star} \\
(0.012)\end{array}$ & $\begin{array}{c}6.724^{\star \star \star} \\
(0.013)\end{array}$ & $\begin{array}{c}7.736^{\star \star \star} \\
(0.349)\end{array}$ & $\begin{array}{c}7.896^{\star * *} \\
(0.332)\end{array}$ & $\begin{array}{l}7.709^{* * *} \\
(0.357)\end{array}$ \\
\hline Observations & 60 & 58 & 60 & 58 & 58 & 60 & 58 \\
\hline $\mathrm{R}^{2}$ & 0.841 & 0.861 & 0.838 & 0.865 & 0.874 & 0.858 & 0.877 \\
\hline $\mathrm{F}$ test & 179.2 & 117.0 & 113.7 & 93.78 & 104.7 & 111.1 & 92.13 \\
\hline $\mathrm{P}$-value $\mathrm{F}$ test & 0 & 0 & 0 & 0 & 0 & 0 & 0 \\
\hline
\end{tabular}

With lagged stocks

\begin{tabular}{ccccccc}
$(8)$ & $(9)$ & $(10)$ & $(11)$ & $(12)$ & $(13)$ & $(14)$ \\
& & & & & & \\
$0.034^{*}$ & $0.038^{*}$ & $0.041^{*}$ & $0.040^{*}$ & $0.036^{*}$ & $0.037^{*}$ & $0.038^{*}$ \\
$(0.020)$ & $(0.020)$ & $(0.021)$ & $(0.021)$ & $(0.021)$ & $(0.021)$ & $(0.021)$ \\
-0.021 & & & & -0.015 & -0.030 & -0.014 \\
$(0.056)$ & & & & $(0.059)$ & $(0.059)$ & $(0.059)$ \\
& 0.019 & & -0.037 & 0.025 & & -0.031 \\
& $(0.078)$ & & $(0.159)$ & $(0.083)$ & & $(0.159)$ \\
& & 0.054 & 0.115 & & 0.071 & 0.113 \\
& & $(0.130)$ & $(0.256)$ & & $(0.138)$ & $(0.257)$ \\
$0.784^{* * *}$ & $0.767^{* * *}$ & $0.784^{* * *}$ & $0.777^{* * *}$ & $0.759^{* * *}$ & $0.770^{* * *}$ & $0.770^{* * *}$ \\
$(0.089)$ & $(0.084)$ & $(0.080)$ & $(0.087)$ & $(0.099)$ & $(0.093)$ & $(0.101)$ \\
$0.089^{*}$ & $0.094^{* *}$ & $0.083^{* *}$ & $0.086^{* *}$ & $0.102^{*}$ & $0.098^{*}$ & 0.093 \\
$(0.048)$ & $(0.036)$ & $(0.032)$ & $(0.040)$ & $(0.057)$ & $(0.052)$ & $(0.058)$ \\
$1.550^{* *}$ & $1.572^{* * *}$ & $1.461^{* * *}$ & $1.503^{* *}$ & $1.686^{*}$ & $1.685^{* *}$ & $1.611^{*}$ \\
$(0.759)$ & $(0.568)$ & $(0.539)$ & $(0.587)$ & $(0.848)$ & $(0.804)$ & $(0.850)$ \\
58 & 57 & 58 & 57 & 57 & 58 & 57 \\
0.941 & 0.942 & 0.941 & 0.942 & 0.942 & 0.942 & 0.942 \\
218.8 & 215.6 & 215.7 & 170.0 & 169.9 & 169.7 & 139.2 \\
0 & 0 & 0 & 0 & 0 & 0 & 0 \\
\hline
\end{tabular}

Forecast price rise

- nominal interest rate

Log U.S. Industrial Production;

Index, 2005=100, Seasonally Adjusted

Actual IP growth

Forecast rate of change of.

U.S. IP, at two-year horizon

Lagged Log US Stocks Crude Oil

Annual trend times 100

Constant

Observations

$\mathrm{R}^{2}$

$\mathrm{F}$ test

0

0

0

${ }^{\star \star *} p<0.01,{ }^{\star \star} p<0.05,{ }^{*} p<0.1 \quad$ (Robust standard errors in parentheses.) 
Table 2b: Global petroleum inventories equation

\begin{tabular}{|c|c|c|c|c|c|c|}
\hline \multicolumn{7}{|c|}{$\begin{array}{l}\text { Dependent Variable: Log World Petroleum Stocks; } \\
\text { Millions of barrels (1995-2011), quarterly observations } \dagger\end{array}$} \\
\hline VARIABLES & $(1)$ & $(2)$ & (3) & $(4)$ & $(5)$ & (6) \\
\hline $\begin{array}{l}\text { Forecast price rise } \\
\text { - Nominal interest rate }\end{array}$ & $\begin{array}{l}0.043^{*} \\
(0.022)\end{array}$ & $\begin{array}{c}0.096^{* * *} \\
(0.021)\end{array}$ & $\begin{array}{c}0.051^{* *} \\
(0.023)\end{array}$ & $\begin{array}{c}0.103^{* * *} \\
(0.023)\end{array}$ & $\begin{array}{c}0.010 \\
(0.016)\end{array}$ & $\begin{array}{c}0.059^{* * *} \\
(0.016)\end{array}$ \\
\hline Lag of Log World Petroleum Stocks & $\begin{array}{l}0.503^{* \star *} \\
(0.152)\end{array}$ & & $\begin{array}{c}0.497^{\star * *} \\
(0.151)\end{array}$ & & $\begin{array}{c}0.640^{* * *} \\
(0.159)\end{array}$ & \\
\hline $\begin{array}{l}\text { Kilian measure of global activity times } 100 ; \\
\text { end of quarter } \dagger \dagger\end{array}$ & $\begin{array}{l}0.016 \\
(0.011)\end{array}$ & $\begin{array}{l}0.033^{* *} \\
(0.012)\end{array}$ & & & & \\
\hline $\begin{array}{l}\text { Kilian measure of global activity times } 100 \\
\text { average of quarter } \dagger \dagger\end{array}$ & & & $\begin{array}{l}0.021^{*} \\
(0.012)\end{array}$ & $\begin{array}{c}0.037^{* * *} \\
(0.013)\end{array}$ & & \\
\hline $\begin{array}{l}\text { Log Quarterly World Real GDP; } \\
\qquad 2005=100\end{array}$ & & & & & $\begin{array}{l}-0.097 \\
(0.079)\end{array}$ & $\begin{array}{c}0.093 \\
(0.083)\end{array}$ \\
\hline Annual trend times 100 & $\begin{array}{l}0.062 \\
(0.041)\end{array}$ & $\begin{array}{c}0.150^{* * *} \\
(0.031)\end{array}$ & $\begin{array}{l}0.057 \\
(0.042)\end{array}$ & $\begin{array}{c}0.144^{\star \star *} \\
(0.032)\end{array}$ & $\begin{array}{l}0.143^{\star *} \\
(0.066)\end{array}$ & $\begin{array}{c}0.119 \\
(0.078)\end{array}$ \\
\hline Constant & $\begin{array}{c}4.111^{\star \star \star} \\
(1.251)\end{array}$ & $\begin{array}{c}8.254^{\star * *} \\
(0.014)\end{array}$ & $\begin{array}{c}4.164^{\star \star \star} \\
(1.238)\end{array}$ & $\begin{array}{c}8.257^{\star \star \star} \\
(0.015)\end{array}$ & $\begin{array}{c}3.386^{\star * \star} \\
(1.215)\end{array}$ & $\begin{array}{c}7.836^{\star * \star} \\
(0.353)\end{array}$ \\
\hline Observations & 40 & 42 & 40 & 42 & 40 & 42 \\
\hline $\mathrm{R}^{2}$ & 0.891 & 0.866 & 0.894 & 0.869 & 0.889 & 0.846 \\
\hline F test & 98.48 & 106.9 & 104.7 & 112.6 & 94.19 & 60.32 \\
\hline P-value $\mathrm{F}$ test & 0 & 0 & 0 & 0 & 0 & 0 \\
\hline${ }^{* * *} p<0.01,{ }^{* *} p<0.05,{ }^{*} p<0.1$ & (Robust & t & $\operatorname{are}$ & es.) & & \\
\hline
\end{tabular}

Table $2 \mathrm{~b}$ reports results from estimating the equation for global petroleum inventories.

The geographical breadth of the global inventory numbers is an advantage. To capture the convenience yield of global inventories we need a corresponding global measure of economic activity. World GDP is the obvious measure. We try this in columns (5) and (6), but it does not seem to work well. We thus try instead, in columns (1)-(4), an alternative measure designed by Lutz Kilian specifically to capture the industrial activity around the world that is most relevant to the demand for oil. The sign on this activity variable turns out always positive and usually significant. 
When the lagged level of global inventories is included it is highly significant and suggests a speed of adjustment of about one half per year. Significance of other variables declines, but not fatally. The speculative variable (expected price change minus interest rate) is still positive and significant. Its estimated short-run coefficient is now about .05.

Table 2c: Global oil inventories equation

\begin{tabular}{|c|c|c|c|c|c|c|}
\hline \multirow[b]{2}{*}{ VARIABLES } & \multirow{2}{*}{\multicolumn{6}{|c|}{ 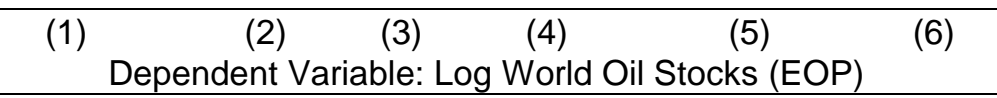 }} \\
\hline & & & & & & \\
\hline Forecast price rise - Nominal interest rate & $\begin{array}{l}0.035^{*} \\
(0.018)\end{array}$ & $\begin{array}{l}0.070^{* * *} \\
(0.014)\end{array}$ & $\begin{array}{l}0.034^{*} \\
(0.018)\end{array}$ & $\begin{array}{l}0.069^{* * *} \\
(0.015)\end{array}$ & $\begin{array}{c}0.026 \\
(0.016)\end{array}$ & $\begin{array}{c}0.061^{* * *} \\
(0.014)\end{array}$ \\
\hline $\begin{array}{l}\text { Kilian measure of global activity } \\
\text { times } 100\end{array}$ & $\begin{array}{c}0.002 \\
(0.010)\end{array}$ & $\begin{array}{l}0.008 \\
(0.011)\end{array}$ & & & & \\
\hline $\begin{array}{l}\text { Lagged log World Petroleum Stocks } \\
\text { EOP }\end{array}$ & $\begin{array}{c}0.441^{* * *} \\
(0.128)\end{array}$ & & $\begin{array}{c}0.443^{* * *} \\
(0.128)\end{array}$ & & $\begin{array}{l}0.469^{* * *} \\
(0.118)\end{array}$ & \\
\hline Annual trend times 100 & $\begin{array}{l}0.210^{* * *} \\
(0.049)\end{array}$ & $\begin{array}{l}0.369^{* * *} \\
(0.014)\end{array}$ & $\begin{array}{r}0.210^{* * *} \\
(0.049)\end{array}$ & $\begin{array}{l}0.370^{\star \star *} \\
(0.014)\end{array}$ & $\begin{array}{l}0.318^{* * *} \\
(0.076)\end{array}$ & $\begin{array}{c}0.435^{* * *} \\
(0.068)\end{array}$ \\
\hline $\begin{array}{l}\text { Kilian measure of global activity; } \\
\text { times 100; quarter average }\end{array}$ & & & $\begin{array}{c}0.001 \\
(0.010)\end{array}$ & $\begin{array}{l}0.007 \\
(0.011)\end{array}$ & & \\
\hline $\begin{array}{l}\text { Log Quarterly World real GDP } \\
\qquad 2005=100\end{array}$ & & & & & $\begin{array}{l}-0.136^{*} \\
(0.075)\end{array}$ & $\begin{array}{l}-0.069 \\
(0.079)\end{array}$ \\
\hline Constant & $\begin{array}{c}4.822^{* * *} \\
(1.105)\end{array}$ & $\begin{array}{c}8.628^{* * *} \\
(0.006)\end{array}$ & $\begin{array}{c}4.809^{\star \star *} \\
(1.100)\end{array}$ & $\begin{array}{c}8.628^{\star * *} \\
(0.006)\end{array}$ & $\begin{array}{c}5.158^{* * *} \\
(1.036)\end{array}$ & $\begin{array}{c}8.918^{\star * *} \\
(0.337)\end{array}$ \\
\hline Observations & 58 & 60 & 58 & 60 & 58 & 60 \\
\hline $\mathrm{R}^{2}$ & 0.971 & 0.964 & 0.971 & 0.964 & 0.972 & 0.964 \\
\hline $\mathrm{F}$ test & 438.8 & 444.2 & 436.9 & 439.4 & 515.3 & 457.8 \\
\hline P-value $F$ test & 0 & 0 & 0 & 0 & 0 & 0 \\
\hline
\end{tabular}

Petroleum inventories is a broad measure, which includes refined products. The specificity of crude oil numbers is preferable. Table $2 \mathrm{c}$ repeats the regression estimates with world oil stocks. The results are similar for the speculative variable and lagged stocks. But the measure of global economic activity is no longer significant. 


\section{Estimation of the Equation to Determine the Price of Oil}

We now turn to estimation of the equation designed to determine the real commodity price, equation (9). For now we continue to focus on oil.

Table 3a reports OLS estimates of the oil price equation. Here the estimated coefficients are of the hypothesized sign for each of the four variables where the theory implies a sign: real interest rates, US economic activity, oil inventories, and risk premium. The coefficient on the real interest rate is always negative as hypothesized, though no longer always significant. Columns (1) through (6) use US inventories of crude oil as the stand-in for storage costs. Accordingly they are careful to use a U.S. measure of economic activity: real US GDP in the first three columns and US industrial production in the next three. The coefficient on US inventories is significantly negative as hypothesized in two out of six cases. The coefficient on GDP is positive and significant in two out of three cases. The coefficient on the risk premium is always positive and significant in 7 out of 9 cases, in the global as well as the US versions of the price equation. The positive coefficient suggests that commodities offer a natural hedging opportunity with respect to the aggregate market portfolio. ${ }^{18}$

\footnotetext{
${ }^{18}$ As noted, Hamilton and $\mathrm{Wu}$ (2013) and Hamilton (2013) suggest that the entry of financial investors into the futures market, via the intermediation of commodity funds, has provided a counterparty for producers wishing to hedge, so that the risk premium has fallen since 2005. Consistent with this story, the risk premium as we measure it, with expectations from survey data, disappeared after 2005.
} 
Table 3a: Estimation of equation for determination of real oil price

\begin{tabular}{|c|c|c|c|c|c|c|c|c|c|}
\hline $\begin{array}{l}\text { OLS } \\
\text { VARIABLES }\end{array}$ & $\begin{array}{c}(1) \\
\text { Depen } \\
\text { 1995-2 }\end{array}$ & $\begin{array}{l}(2) \\
\text { ent vari } \\
11,24 \mathrm{q}\end{array}$ & $\begin{array}{l}\text { (3) } \\
\text { ole: Log } \\
\text { arterly }\end{array}$ & $\begin{array}{c}(4) \\
\text { of real o } \\
\text { servati }\end{array}$ & $\begin{array}{c}\text { (5) } \\
\text { price, } \\
\text { nst }\end{array}$ & (6) & (7) & (8) & (9) \\
\hline $\begin{array}{l}\text { Real interest rate } \\
\text { quarterly }\end{array}$ & $\begin{array}{l}-1.234 \\
(0.761)\end{array}$ & $\begin{array}{l}-1.296 \\
(0.853)\end{array}$ & $\begin{array}{l}-1.393 \\
(0.851)\end{array}$ & $\begin{array}{l}-1.281 \\
(0.789)\end{array}$ & $\begin{array}{l}-2.012 \\
(1.248)\end{array}$ & $\begin{array}{l}-1.993 \\
(1.300)\end{array}$ & $\begin{array}{l}-0.362 \\
(0.654)\end{array}$ & $\begin{array}{l}-2.192^{* * *} \\
(0.631)\end{array}$ & $\begin{array}{l}-2.221^{\star * *} \\
(0.644)\end{array}$ \\
\hline $\begin{array}{l}\text { Risk Premium }=\log (\text { futures } / \text { spot }) \\
\text { - (survey-expected } \Delta \text { log oil price) }\end{array}$ & $\begin{array}{l}1.241^{* * *} \\
(0.372)\end{array}$ & $\begin{array}{l}0.864^{\star \star} \\
(0.397)\end{array}$ & $\begin{array}{l}0.714^{*} \\
(0.388)\end{array}$ & $\begin{array}{l}1.266^{\star \star *} \\
(0.349)\end{array}$ & $\begin{array}{c}0.969 \\
(0.638)\end{array}$ & $\begin{array}{c}0.989 \\
(0.648)\end{array}$ & $\begin{array}{l}1.776^{\star \star \star} \\
(0.380)\end{array}$ & $\begin{array}{l}1.478^{\star *} \\
(0.556)\end{array}$ & $\begin{array}{l}1.483^{\star *} \\
(0.574)\end{array}$ \\
\hline $\begin{array}{l}\text { Option-Implied volatility } \\
100 \% \text { moneyness; } 1 \text { st day of month }\end{array}$ & $\begin{array}{l}-0.198 \\
(7.504)\end{array}$ & $\begin{array}{l}9.621 \\
(6.478)\end{array}$ & $\begin{array}{l}15.73^{\star *} \\
(7.099)\end{array}$ & $\begin{array}{l}-0.405 \\
(6.756)\end{array}$ & $\begin{array}{c}12.07 \\
(9.058)\end{array}$ & $\begin{array}{c}11.22 \\
(10.03)\end{array}$ & $\begin{array}{l}1.858 \\
(8.134)\end{array}$ & $\begin{array}{c}4.094 \\
(8.890)\end{array}$ & $\begin{array}{l}2.615 \\
(9.427)\end{array}$ \\
\hline $\begin{array}{l}\text { Volatility } \\
\text { (std.dev of price over last quarter ) }\end{array}$ & & & $\begin{array}{l}-11.17 \\
(11.52)\end{array}$ & & & $\begin{array}{c}1.449 \\
(15.77)\end{array}$ & & & $\begin{array}{l}2.576 \\
(13.56)\end{array}$ \\
\hline $\begin{array}{l}\text { Log U.S. Stocks Crude Oil } \\
\text { (millions of barrels) }\end{array}$ & $\begin{array}{l}-2.914^{\star *} \\
(1.214)\end{array}$ & $\begin{array}{c}0.105 \\
(1.093)\end{array}$ & $\begin{array}{l}-0.517 \\
(1.228)\end{array}$ & $\begin{array}{l}-3.075^{\star *} \\
(1.178)\end{array}$ & $\begin{array}{c}1.111 \\
(1.508)\end{array}$ & $\begin{array}{c}1.176 \\
(1.712)\end{array}$ & & & \\
\hline $\begin{array}{l}\text { Log US Quarterly Real GDP } \\
\text { (constant } 2005 \text { US\$);WDI }\end{array}$ & $\begin{array}{c}1.354 \\
(2.655)\end{array}$ & $\begin{array}{l}8.087^{\star * *} \\
(1.163)\end{array}$ & $\begin{array}{l}8.612^{\star \star *} \\
(1.572)\end{array}$ & & & & & & \\
\hline $\begin{array}{l}\text { Log U.S. Industrial Production; } \\
\text { Index, } 2005=100 \text {, seas.adj. }\end{array}$ & & & & $\begin{array}{c}0.422 \\
(0.844)\end{array}$ & $\begin{array}{c}1.974 \\
(1.477)\end{array}$ & $\begin{array}{c}1.945 \\
(1.534)\end{array}$ & & & \\
\hline $\begin{array}{l}\text { Kilian global activity measure } \\
\text { times } 100+\dagger\end{array}$ & & & & & & & $\begin{array}{l}-0.082 \\
(0.152)\end{array}$ & $\begin{array}{l}-0.320 \\
(0.209)\end{array}$ & $\begin{array}{l}-0.318 \\
(0.221)\end{array}$ \\
\hline $\begin{array}{l}\text { World Petroleum Stocks } \\
\text { (billions of barrels) }\end{array}$ & & & & & & & $\begin{array}{l}-0.323 \\
(0.407)\end{array}$ & $\begin{array}{l}-0.064 \\
(0.561)\end{array}$ & $\begin{array}{l}-0.047 \\
(0.593)\end{array}$ \\
\hline Trend & $\begin{array}{c}0.022^{* *} \\
-0.009\end{array}$ & - & - & $\begin{array}{c}0.025^{\star * *} \\
-0.005\end{array}$ & & & $\begin{array}{c}0.020^{\star * *} \\
-0.004\end{array}$ & & \\
\hline Constant & $\begin{array}{l}-4.202 \\
(47.48)\end{array}$ & $\begin{array}{c}134.6^{\star * *} \\
(20.68)\end{array}$ & $\begin{array}{c}139.0^{\star * *} \\
(24.62)\end{array}$ & $\begin{array}{c}17.02 \\
(9.838)\end{array}$ & $\begin{array}{l}-18.22 \\
(13.27)\end{array}$ & $\begin{array}{l}-18.53 \\
(14.27)\end{array}$ & $\begin{array}{l}-0.823 \\
(1.641)\end{array}$ & $\begin{array}{l}-0.856 \\
(2.310)\end{array}$ & $\begin{array}{l}-0.897 \\
(2.410)\end{array}$ \\
\hline Observations & 24 & 24 & 24 & 24 & 24 & 24 & 24 & 24 & 24 \\
\hline R-squared & 0.853 & 0.802 & 0.813 & 0.853 & 0.584 & 0.584 & 0.798 & 0.606 & 0.606 \\
\hline F test & 11.47 & 16.78 & 13.57 & 12.01 & 5.629 & 4.821 & 12.52 & 6.218 & 5.597 \\
\hline
\end{tabular}

${ }^{* * *} p<0.01,{ }^{* *} p<0.05,{ }^{*} p<0.1 \quad$ (Robust standard errors in parentheses.)

$\dagger$ Year 2007 has 3 data points .

†† end-of-quarter, based on the monthly industrial activity measure of Baumeister and Kilian (2012a,b). 
Volatility usually appears with a positive coefficient, whether measured by means of oil options or by means of lagged actual spot price variability. It is seldom statistically significant, but this is not necessarily disturbing, since the theoretical effects are ambiguous.

The last three columns, (7) through (9), move to the global level. The coefficient on global petroleum stocks is always negative, as hypothesized, but never significant. The coefficient on the economic activity variable is negative and also insignificant. The real interest rate and risk premium are of the right sign and mostly significant.

Most of our right-hand side variables could well be endogenous. Perhaps, then, we should describe the statistical associations more neutrally, as "estimated coefficients," rather than "effects." One could argue that for an individual minor commodity, economy-wide variables such as GDP and interest rates can be taken as exogenous. When the commodity is as important to the world economy as oil, reverse causality is relevant. An exogenous increase in the price of oil, due for example to 1970s-type supply disruptions, is likely to lead the central bank to raise interest rates in an attempt to limit inflation. But if this is the nature of the reverse causality, it would suggest a positive association between commodity prices and interest rates, whereas we find a negative relationship. Similarly, an increase in the price of oil due to supply disruptions is likely to lead to a fall in economic activity; but we find a positive association.

Because we estimated an equation to determine inventories in the preceding section, there is some extra obligation to treat inventories as endogenous in this section. Table $3 \mathrm{~b}$ makes an attempt at instrumental variables (available in Appendix II of $\underline{\text { HKS RWP13-022 }}$ or the version to be published in the JIE). Although the preferred way of instrumenting uses both the Kilian oil shock variable and lagged inventories, in some cases we have to drop the former because it is not available after 2004 . 
The results are disappointing. The coefficients on stocks are always insignificant. The coefficient on economic activity is usually insignificant, or else of the incorrect sign. The coefficient on the real interest rate is not significantly less than zero. Only the coefficient on the risk premium remains positive and consistently significant. The problem might be that the Kilian oil shock variable is an inadequate instrument for inventories. A related problem may be the small number of observations that are available. Any further attempts to correct for endogeneity evidently must await the discovery of better instrumental variables.

\section{Estimation of the Equation to Determine the Prices of 11 Commodities}

Next we attempt to extend the estimation to a wider set of mineral and agricultural commodities. To do so, we lose the data that made possible several useful measures: the optionimplied volatility measure, the survey-based forecasts of future commodity prices [which are available only for oil, silver and gold], the Kilian measure of industrial activity, and the Kilian measure of oil shocks.

The price equation is estimated for 11 commodities in Table 4a. The coefficient on the real interest rate is negative for 9 out of 11 commodities and statistically significant for 6 out of

the 9. The coefficient on World GDP is positive for 8 out of 11 , but significant for only 3 out of the 8 . The coefficient on inventories is negative for 7 out of 11 , and significant for 4 out of 7 . The coefficient on the spread is significantly negative for 5 commodities and actual volatility significantly positive for 5 . 
Table 4a: Estimation of equations for determination of individual real commodity prices. 1950-2012, annual observations $\dagger$

\begin{tabular}{|c|c|c|c|c|c|c|}
\hline $\begin{array}{r}\text { Table } 4 \mathrm{a}--1^{\text {st }} \text { half } \\
\text { Commodity: }\end{array}$ & $\begin{array}{c}(1) \\
\text { Copper }\end{array}$ & $\begin{array}{l}(2) \\
\text { Corn } \\
\end{array}$ & $\begin{array}{l}(3) \\
\text { Cotton }\end{array}$ & $\begin{array}{c}(4) \\
\text { Live cattle }\end{array}$ & $\begin{array}{c}(5) \\
\text { Live hogs } \\
\end{array}$ & \\
\hline VARIABLES & & & & & & \\
\hline Real interest rate & $\begin{array}{c}-0.066^{\star * *} \\
(0.018)\end{array}$ & $\begin{array}{l}-0.046^{*} \\
(0.026)\end{array}$ & $\begin{array}{c}0.005 \\
(0.014)\end{array}$ & $\begin{array}{c}-0.052^{\star \star \star} \\
(0.018)\end{array}$ & $\begin{array}{l}-0.038^{\star \star \star} \\
(0.009)\end{array}$ & \\
\hline $\begin{array}{l}\text { Log World GDP } \\
\text { (constant 2000US\$);WDI }\end{array}$ & $\begin{array}{l}-0.465 \\
(0.570)\end{array}$ & $\begin{array}{l}0.616 \\
(0.574)\end{array}$ & $\begin{array}{l}0.560 \\
(0.578)\end{array}$ & $\begin{array}{c}2.260 \\
(1.475)\end{array}$ & $\begin{array}{l}-2.619^{\star \star} \\
(1.119)\end{array}$ & \\
\hline Log Inventories * & $\begin{array}{c}-0.190^{\star * *} \\
(0.056)\end{array}$ & $\begin{array}{l}-0.075 \\
(0.172)\end{array}$ & $\begin{array}{l}-0.134 \\
(0.117)\end{array}$ & $\begin{array}{l}1.122 \\
(0.784)\end{array}$ & $\begin{array}{l}0.419^{*} \\
(0.245)\end{array}$ & \\
\hline $\begin{array}{l}\text { Spread, \% } \\
\text { Future-Spot }\end{array}$ & $\begin{array}{l}0.000 \\
(0.002)\end{array}$ & $\begin{array}{l}-0.006 \\
(0.003)\end{array}$ & $\begin{array}{l}-0.001 \\
(0.001)\end{array}$ & $\begin{array}{c}-0.007^{\star * *} \\
(0.002)\end{array}$ & $\begin{array}{c}-0.004^{\star \star \star} \\
(0.001)\end{array}$ & \\
\hline $\begin{array}{l}\text { Volatility; Std.dev. } \\
\text { of log price over past year }\end{array}$ & $\begin{array}{c}3.038^{\star * *} \\
(0.720)\end{array}$ & $\begin{array}{c}0.937 \\
(0.909)\end{array}$ & $\begin{array}{c}0.203 \\
(0.527)\end{array}$ & $\begin{array}{l}-0.275 \\
(0.778)\end{array}$ & $\begin{array}{l}-1.017 \\
(0.609)\end{array}$ & \\
\hline Linear trend & $\begin{array}{l}-0.002 \\
(0.020)\end{array}$ & $\begin{array}{l}-0.041^{* *} \\
(0.020)\end{array}$ & $\begin{array}{l}-0.038^{*} \\
(0.020)\end{array}$ & $\begin{array}{l}-0.078^{*} \\
(0.042)\end{array}$ & $\begin{array}{c}0.054 \\
(0.033)\end{array}$ & \\
\hline Constant & $\begin{array}{c}16.938 \\
(17.288)\end{array}$ & $\begin{array}{l}-20.259 \\
(16.542)\end{array}$ & $\begin{array}{l}-14.944 \\
(17.291)\end{array}$ & $\begin{array}{l}-81.651 \\
(51.771)\end{array}$ & $\begin{array}{l}74.873^{* *} \\
(33.004)\end{array}$ & \\
\hline $\begin{array}{l}\text { Observations } \\
\mathrm{R}^{2}\end{array}$ & $\begin{array}{c}50 \\
0.549\end{array}$ & $\begin{array}{c}51 \\
0.660\end{array}$ & $\begin{array}{c}51 \\
0.760\end{array}$ & $\begin{array}{c}32 \\
0.511\end{array}$ & $\begin{array}{c}39 \\
0.802\end{array}$ & \\
\hline $\begin{array}{r}\text { Table } 4 \mathrm{a}--2^{\text {nd }} \text { half } \\
\text { Commodity: }\end{array}$ & $\begin{array}{l}(6) \\
\text { Oats } \\
\end{array}$ & $\begin{array}{c}(7) \\
\text { Petroleum }\end{array}$ & $\begin{array}{c}(8) \\
\text { Platinum }\end{array}$ & $\begin{array}{c}(9) \\
\text { Silver }\end{array}$ & $\begin{array}{c}(10) \\
\text { Soybeans }\end{array}$ & $\begin{array}{c}(11) \\
\text { Wheat }\end{array}$ \\
\hline VARIABLES & & & & & & \\
\hline Real interest rate & $\begin{array}{c}-0.037^{\star *} \\
(0.016)\end{array}$ & $\begin{array}{l}-0.015 \\
(0.071)\end{array}$ & $\begin{array}{l}0.081^{* \star *} \\
(0.015)\end{array}$ & $\begin{array}{l}-0.016 \\
(0.025)\end{array}$ & $\begin{array}{c}-0.040^{\star *} \\
(0.016)\end{array}$ & $\begin{array}{l}-0.003 \\
(0.021)\end{array}$ \\
\hline $\begin{array}{l}\text { Log World GDP } \\
\text { (constant 2000US\$);WDI }\end{array}$ & $\begin{array}{l}1.555^{\star \star} \\
(0.593)\end{array}$ & $\begin{array}{l}-4.423 \\
(4.984)\end{array}$ & $\begin{array}{c}3.378^{\star \star \star} \\
(0.753)\end{array}$ & $\begin{array}{l}3.625^{*} \\
(2.012)\end{array}$ & $\begin{array}{c}0.377 \\
(0.837)\end{array}$ & $\begin{array}{c}0.325 \\
(0.702)\end{array}$ \\
\hline Log Inventories * & $\begin{array}{l}-0.311^{\star \star} \\
(0.135)\end{array}$ & $\begin{array}{l}-2.815 \\
(4.432)\end{array}$ & $\begin{array}{l}-0.243^{\star \star \star} \\
(0.030)\end{array}$ & $\begin{array}{c}0.005 \\
(0.106)\end{array}$ & $\begin{array}{c}0.043 \\
(0.086)\end{array}$ & $\begin{array}{l}-0.453^{*} \\
(0.238)\end{array}$ \\
\hline $\begin{array}{r}\text { Spread, \% } \\
\text { Future-Spot }\end{array}$ & $\begin{array}{l}-0.005^{\star} \\
(0.003)\end{array}$ & $\begin{array}{l}-0.002 \\
(0.003)\end{array}$ & $\begin{array}{l}-0.000 \\
(0.001)\end{array}$ & $\begin{array}{l}-0.010^{\star *} \\
(0.004)\end{array}$ & $\begin{array}{l}-0.007^{\star *} \\
(0.003)\end{array}$ & $\begin{array}{l}-0.001 \\
(0.003)\end{array}$ \\
\hline $\begin{array}{l}\text { Volatility; Std.dev. } \\
\text { of log price over past year }\end{array}$ & $\begin{array}{c}0.905 \\
(0.665)\end{array}$ & $\begin{array}{l}-0.082 \\
(0.691)\end{array}$ & $\begin{array}{l}1.096^{* * *} \\
(0.356)\end{array}$ & $\begin{array}{c}5.148^{\star \star \star} \\
(0.666)\end{array}$ & $\begin{array}{l}1.861^{\star *} \\
(0.868)\end{array}$ & $\begin{array}{c}1.812^{\star \star \star} \\
(0.650)\end{array}$ \\
\hline Linear trend & $\begin{array}{c}-0.085^{\star \star \star} \\
(0.026)\end{array}$ & $\begin{array}{c}0.172 \\
(0.137)\end{array}$ & $\begin{array}{c}-0.123^{\star \star \star} \\
(0.027)\end{array}$ & $\begin{array}{l}-0.119^{*} \\
(0.063)\end{array}$ & $\begin{array}{l}-0.036 \\
(0.027)\end{array}$ & $\begin{array}{l}-0.026 \\
(0.022)\end{array}$ \\
\hline Constant & $\begin{array}{l}-45.541^{\star * *} \\
(16.331)\end{array}$ & $\begin{array}{c}156.653 \\
(142.648)\end{array}$ & $\begin{array}{l}-98.356^{\star * \star} \\
(22.409)\end{array}$ & $\begin{array}{c}-111.768^{*} \\
(60.573)\end{array}$ & $\begin{array}{l}-13.651 \\
(24.707)\end{array}$ & $\begin{array}{l}-7.089 \\
(20.177)\end{array}$ \\
\hline $\begin{array}{l}\text { Observations } \\
\mathrm{R}^{2}\end{array}$ & $\begin{array}{c}50 \\
0.634\end{array}$ & $\begin{array}{c}29 \\
0.336\end{array}$ & $\begin{array}{c}47 \\
0.733\end{array}$ & $\begin{array}{c}44 \\
0.612\end{array}$ & $\begin{array}{c}48 \\
0.709\end{array}$ & $\begin{array}{c}51 \\
0.737\end{array}$ \\
\hline
\end{tabular}

${ }^{* * *} p<0.01,{ }^{* *} p<0.05,{ }^{*} p<0.1 \quad$ (Robust standard errors in parentheses.)

$\uparrow$ Some commodities have shorter sample periods due to data availability, as indicated in the number of observations.

* Copper, Live Cattle, Live Hog, Oats, Platinum and Silver use U.S. inventories. The others use global inventories. 
Table $4 \mathrm{~b}$ estimates the same equations in terms of first differences. ${ }^{19}$ The results are similar, but not as strong. First, the coefficient on the real interest rate is negative in 10 out of 11 cases, but significant in only three, and only at the $10 \%$ level. Second, for the economic activity variable we try the Consensus forecast of the rate of change of industrial production in the year of observation and the subsequent year. The motivation is that expectations of rapid growth might add to the current demand for commodities. The coefficient is positive in 9 cases and significant in 6 of those 9. Third, the coefficient on inventories is often of the wrong sign; but then we no longer are controlling for survey forecasts of price increases, and their positive effect could possibly be showing up via inventories.

To summarize the results for individual commodities, the real interest rate and inventories both often show up with the hypothesized negative coefficients in the equations for the real prices of individual commodities. But the levels of statistical significance are low, especially when controlling for the lagged commodity price.

Analysing commodities one by one might give weaker results than when the data are pooled. For one thing, because we are working with annual data here, each regression has relatively few observations. For another thing, we know that we have not captured the many idiosyncratic forces such as weather events that lead to bad harvests in some agricultural commodities or high demand for fuels. Accordingly we now turn to panel regressions, where the number of observations is much larger and we can hope that some sector-specific idiosyncratic factors will largely wash out.

\footnotetext{
${ }^{19}$ To address concerns of high autocorrelation. Available in Appendix II of HKS RWP13-022 or the version forthcoming in the Journal of International Economics.
} 
The estimated coefficient on the real interest rate in the panel regression in Table $5 \mathrm{a}$ is negative in 6 permutations, and significant in 3 of them. The coefficient on inventories is in all cases negative as hypothesized, and is in all cases highly significant statistically. The coefficient on the forward-spot spread is significantly negative in all cases. This is consistent with the earlier intuition that when the term structure is in contango (i.e., the spread $f-s$ is high), the market is soft. The coefficient on actual volatility is significantly positive in all.

Among the economic activity variables, the positive coefficient on Global GDP is significant when the linear trend time term is supplemented by a quadratic. Consistent with this finding, when world GDP is de-trended by means of a Hodrick-Prescott filter, giving us a variable we call Business Cycle, its positive coefficient is again highly significant.

Table 5: Estimation of equation for determination of real commodity prices in a panel

\begin{tabular}{|c|c|c|c|c|c|c|c|}
\hline $\begin{array}{l}\text { Table 5a: Panel -- real prices } \\
\text { of } 11 \text { commodities (annual) }\end{array}$ & (1) & (2) & (3) & (4) & (5) & (6) & (7) \\
\hline \multicolumn{8}{|l|}{ VARIABLES } \\
\hline Real interest rate & $\begin{array}{l}-0.024^{*} \\
(0.013)\end{array}$ & $\begin{array}{l}-0.021^{*} \\
(0.011)\end{array}$ & $\begin{array}{l}-0.010 \\
(0.010)\end{array}$ & $\begin{array}{l}-0.010 \\
(0.013)\end{array}$ & $\begin{array}{l}-0.010 \\
(0.012)\end{array}$ & $\begin{array}{l}-0.032^{* *} \\
(0.014)\end{array}$ & $\begin{array}{c}0.009 \\
(0.010)\end{array}$ \\
\hline $\begin{array}{l}\text { Log World GDP } \\
\text { (constant } 2000 \text { US\$); WDI }\end{array}$ & $\begin{array}{c}0.011 \\
(0.236)\end{array}$ & $\begin{array}{l}0.415 \\
(0.401)\end{array}$ & & & & & $\begin{array}{l}3.447^{* * *} \\
(0.770)\end{array}$ \\
\hline Log Inventories & $\begin{array}{l}-0.141^{* \star *} \\
(0.026)\end{array}$ & $\begin{array}{c}-0.154^{\star \star *} \\
(0.027)\end{array}$ & $\begin{array}{c}-0.124^{\star \star \star} \\
(0.037)\end{array}$ & $\begin{array}{c}-0.164^{\star \star *} \\
(0.023)\end{array}$ & $\begin{array}{c}-0.111^{\star * *} \\
(0.024)\end{array}$ & $\begin{array}{c}-0.138^{\star \star \star} \\
(0.024)\end{array}$ & $\begin{array}{c}-0.133^{\star \star \star} \\
(0.022)\end{array}$ \\
\hline Future-Spot Spread, \% & $\begin{array}{l}-0.003^{* * *} \\
(0.001)\end{array}$ & & $\begin{array}{l}-0.003^{* \star *} \\
(0.001)\end{array}$ & $\begin{array}{c}-0.003^{* * *} \\
(0.001)\end{array}$ & $\begin{array}{c}-0.004^{* * *} \\
(0.001)\end{array}$ & $\begin{array}{c}-0.003^{\star \star *} \\
(0.001)\end{array}$ & $\begin{array}{l}-0.003^{\star \star \star} \\
(0.000)\end{array}$ \\
\hline $\begin{array}{l}\text { Volatility: Std.dev. of } \\
\text { log spot price of past year }\end{array}$ & $\begin{array}{l}1.811^{* * *} \\
(0.520)\end{array}$ & $\begin{array}{l}1.640^{\star * *} \\
(0.468)\end{array}$ & $\begin{array}{l}0.844^{*} \\
(0.402)\end{array}$ & $\begin{array}{l}1.850^{* *} \\
(0.585)\end{array}$ & $\begin{array}{l}1.325^{\star \star} \\
(0.424)\end{array}$ & $\begin{array}{l}1.915^{* * *} \\
(0.510)\end{array}$ & $\begin{array}{l}1.774^{* * *} \\
(0.468)\end{array}$ \\
\hline Linear Trend & $\begin{array}{l}-0.017^{*} \\
(0.008)\end{array}$ & $\begin{array}{l}-0.028^{*} \\
(0.013)\end{array}$ & $\begin{array}{l}0.015^{*} \\
(0.008)\end{array}$ & $\begin{array}{c}-0.021^{* * *} \\
(0.002)\end{array}$ & $\begin{array}{l}-0.002 \\
(0.004)\end{array}$ & $\begin{array}{c}-0.017^{\star * *} \\
(0.002)\end{array}$ & $\begin{array}{l}-0.192^{\star \star \star} \\
(0.041)\end{array}$ \\
\hline Constant & $\begin{array}{l}0.006 \\
(7.012)\end{array}$ & $\begin{array}{l}-11.854 \\
(11.869)\end{array}$ & $\begin{array}{l}-0.462 \\
(0.415)\end{array}$ & $\begin{array}{l}0.479^{*} \\
(0.221)\end{array}$ & $\begin{array}{l}-0.508^{*} \\
(0.269)\end{array}$ & $\begin{array}{c}0.323 \\
(0.229)\end{array}$ & $\begin{array}{c}-101.896^{* * *} \\
(22.926)\end{array}$ \\
\hline $\begin{array}{l}\text { Forecast 2-yr.US GDP growth } \\
\text { (Consensus Forecasts monthly) }\end{array}$ & & & $\begin{array}{l}-3.726 \\
(2.092)\end{array}$ & & & & \\
\hline $\begin{array}{l}\text { Global Business Cycle } \\
\text { (HP-Filtered World GDP) }\end{array}$ & & & & & & $\begin{array}{c}7.219^{\star \star \star} \\
(1.083)\end{array}$ & \\
\hline Quadratic Trend & & & & & & & $\begin{array}{l}0.001^{* * *} \\
(0.000)\end{array}$ \\
\hline Observations & 492 & 536 & 216 & 403 & 293 & 492 & 492 \\
\hline
\end{tabular}




$\begin{array}{lccccccc}\mathrm{R}^{2} & 0.456 & 0.400 & 0.365 & 0.487 & 0.216 & 0.486 & 0.512 \\ { }^{* \star *} \mathrm{p}<0.01,{ }^{* \star} \mathrm{p}<0.05,{ }^{*} \mathrm{p}<0.1 & \text { (Robust standard errors in parentheses.) }\end{array}$

Table 5b, reported in Appendix II of HKS RWP13-022, estimates the equation in firstdifference form. The forecasted rate of US growth is significantly positive in the 3 permutations where it is tried, as is H-P-filtered world GDP ("Global Business Cycle") and OECD estimates of the output gap. In both tables, it is reassuring to see that bringing more data to bear at once, through the panel, has led to stronger results for the negative effects of real interest rates and the positive effects of economic activity, the spread, and volatility.

Table $5 \mathrm{c}$ uses a lagged endogenous variable instead of first differencing. ${ }^{20}$ The coefficient on the real interest rate is negative in 8 out of 11 cases, but no longer significant in most cases. For the activity variable we try World GDP, but its coefficient is rarely significantly greater than zero. The coefficient on inventories is now of the hypothesized negative sign in 10 out of 11 cases, and significant in three.

\section{Summary and Conclusion}

This paper has presented a model that can accommodate each of the prominent explanations that were given for recent increases in the prices of oil and most other agricultural and mineral commodities: economic activity, easy monetary policy, and speculation. It has gone beyond past research in using survey data to measure the forecasts of market participants ("speculation") and using options data to measure the implicit variance ("risk").

\footnotetext{
${ }^{20}$ To avoid dangers of nonstationarity. Reported in Appendix II of $\underline{\text { HKS RWP13-022 }}$ or the JIE version.
} 
The theoretical model is built around the 'arbitrage' decision faced by any firm holding inventories. This is the tradeoff between the costs of carrying the inventory on the one hand (the interest rate plus the cost of storage) versus the convenience yield and forward-spot spread (or, if unhedged, the expected capital gain adjusted for the risk premium) on the other hand. A second equation completes the picture: the real commodity price is expected to regress gradually back to its long run equilibrium. The reduced form equation expresses the real commodity price as a function of the real interest rate, storage costs, convenience yield and the risk premium. The level of inventories is a ready stand-in for storage costs and economic activity is a determinant of convenience yield.

The empirical significance of the inventory variable suggests that the data and relationship are meaningful, notwithstanding fears that the available measures of inventories are incomplete. Economic activity is an important determinant of the convenience yield and thereby of the demand for inventory holdings and the price of the commodity. The risk premium, directly measured by means of the survey data, is statistically significant. Measures of risk based on either actual volatility or option-implied volatility constitute other potentially important determinants, though there is only rather limited evidence in support of them here.

The significance of the inventories variable in the panel regressions for determination of commodity prices supports the legitimacy of arguments by others who have used observed inventory levels to gauge the roles of speculation or interest rates. There was support in these new results for the hypothesis that low real interest rates are an important source of upward pressure on real commodity prices, via a high demand for inventories (among other channels), beyond any effect that easy monetary policy might have via real economic activity. An important qualification is that we have not dealt with the possible endogeneity of the real interest 
rate and other explanatory variables. One could also refine the time series techniques. Much remains to be done, especially if more data could be brought to bear.

\section{References}

Abosedra, Salah and Stanislav Radchenko (2003), “Oil Stock Management and Futures Prices: An Empirical Analysis," Journal of Energy and Development, vol. 28, no. 2, Spring, pp. 173-88.

Alquist, Ron, and Lutz Kilian (2010), "What do we learn from the price of crude oil futures?" Journal of Applied Econometrics (John Wiley and Sons, Ltd.), vol. 25, no.4, pp.539-573.

Alquist, Ron, Lutz Kilian, and Robert Vigfusson (2011), "Forecasting the Price of Oil," Working Papers 11-15, Bank of Canada. Handbook, forthcoming.

Balabanoff, Stefan (1995), "Oil Futures Prices and Stock Management: A Cointegration Analysis,” Energy Economics, vol. 17, no. 3, July, pp. 205-10.

Barsky, Robert, and Lutz Kilian (2002), "Do We Really Know That Oil Caused the Great Stagflation? A Monetary Alternative," in NBER Macroeconomics Annual 2001, B. Bernanke and K. Rogoff (eds), MIT Press, Cambridge, 137-183.

Barsky, Robert, and Lutz Kilian (2004), “Oil and the Macroeconomy Since the 1970s," Journal of Economic Perspectives 18(4), 115-134.

Baumeister, Christiane, and Lutz Kilian (2012a), "Real-Time Forecasts of the Real Price of Oil," Journal of Business and Economic Statistics, American Statistical Association, vol. 30(2), pages 326-336, April .

Baumeister, Christiane, and Lutz Kilian (2012b), "What Central Bankers Need to Know about Forecasting Oil Prices," CEPR Discussion Papers 9118.

Bessimbinder, Hendrik (1993), “An Empirical Analysis of Risk Premia in Futures Markets,” Journal of Futures Markets, 13, pp. 611-630.

Bhardwaj, Geetesh, Gary Gorton, K. Geert Rouwenhorst (2008), "Fooling Some of the People All of the Time: The Inefficient Performance and Persistence of Commodity Trading Advisors," NBER WP No. 14424. October.

Bopp, A.E., and G.M. Lady (1991), “A Comparison of Petroleum Futures versus Spot Prices as Predictors of Prices in the Future," Energy Economics 13, 274-282.

Breeden, Douglas (1980), “Consumption Risks in Futures Markets,” Journal of Finance, vol. 35, May, pp. 503-20.

Calvo, Guillermo (2008), "Exploding Commodity Prices, Lax Monetary Policy, and Sovereign Wealth Funds," Vox, June 20, http://www.voxeu.org/index.php?q=node/1244\#fn5 .

Chernenko, S., K. Schwarz, and J.H. Wright (2004), “The Information Content of Forward and Futures Prices: Market Expectations and the Price of Risk," Federal Reserve Board International Finance Discussion Paper 808.

Chinn, Menzie, M. Le Blanch and O. Coibion (2005), “The Predictive Content of Energy Futures: An Update on Petroleum, Natural Gas, Heating Oil and Gasoline,” NBER Working Paper 11033. 
Choe, Boum-Jong (1990), "Rational Expectations and Commodity Price Forecasts,“ World Bank Policy Research Working Paper Series 435.

Covey, Ted, and David Bessler (1995), "Asset Storability and the Information Content of Intertemporal Prices," Journal of Empirical Finance, 2, pp. 103-15.

Deaton, Angus, and Guy Laroque (1996), "Competitive Storage and Commodity Price Dynamics," Journal of Political Economy, Vol. 104, No. 5, Oct., pp. 896-923.

Dornbusch, Rudiger (1976), "Expectations and Exchange Rate Dynamics," Journal of Political Economy 84, pp. 1161-1176.

Dusak, Katherine (1973), "Futures Trading and Investor Returns: An Investigation of Commodity Market Risk Premiums," Journal of Political Economy, 81, pp. 1387-1406.

Fama, Eugene, and French, Kenneth (1987), "Commodity futures prices: Some Evidence on Forecast Power, Premiums, and the Theory of Storage," Journal of Business, 60, pp. 55-73.

Frankel, Jeffrey (1984), “Commodity Prices and Money: Lessons from International Finance,” American Journal of Agricultural Economics 66, no. 5 December, pp. 560-566.

Frankel, Jeffrey (1986), "Expectations and Commodity Price Dynamics: The Overshooting Model," American Journal of Agricultural Economics_68, no.2, May, 344-48. Reprinted in Frankel, Financial Markets and Monetary Policy (MIT Press) 1995.

Frankel, Jeffrey (2008a), "The Effect of Monetary Policy on Real Commodity Prices," in Asset Prices and Monetary Policy, John Campbell, ed., University of Chicago Press, pp. 291-327.

Frankel, Jeffrey (2008b), “An Explanation for Soaring Commodity Prices,” Vox, March 25. At http://www.voxeu.org/index.php?q=node/1002.

Frankel, Jeffrey, and Gikas Hardouvelis (1985), "Commodity Prices, Money Surprises, and Fed Credibility" Journal of Money, Credit and Banking 17, no. 4 (Nov., Part I) pp. 427-438. Reprinted in Frankel, Financial Markets and Monetary Policy, MIT Press, 1995.

Frankel, Jeffrey, and Andrew Rose (2009), "Determinants of Agricultural and Mineral Commodity Prices," in Inflation in an Era of Relative Price Shocks (Reserve Bank of Australia).

Gorton, Gary and K. Geert Rouwenhorst (2006), "Facts and Fantasies about Commodity Futures,” Financial Analysts Journal, vol. 62 (2, March/April) 47-68.

Gorton, Gary, Fumio Hayashi and K. Geert Rouwenhorst (2007), "The Fundamentals of Commodity Futures Returns,” NBER Working Paper No. 13249, July.

Greenland, S.L., and Knut Mork (1991), "Towards Efficiency in the Crude Oil Market” Journal of Applied Economics," 6, pp. 45-66.

Hamilton, James, 2008, “Would you like anything else with that coffee, Ben?” EcoBrowser, March 26.

Hamilton, James, 2009, "Causes and Consequences of the Oil Shock of 2007-08," Brookings Papers on Economic Activity, Spring, pp. 215-259.

Hamilton, James, 2013, "Risk Premia in Crude Oil Futures Prices," in Understanding International Commodity Price Fluctuations, conference organized by the IMF Research Department and the Oxford Centre for the Analysis of Resource Rich Economies.

Hamilton, James, and Jing Cynthia Wu, 2013, "Effective of Index Fund Investing on Commodity Futures Prices." 
Keynes, John Maynard, 1930, A Treatise on Money, Volume 2 (Macmillan: London).

Kilian, Lutz, and Bruce Hicks, 2012, "Did Unexpectedly Strong Economic Growth Cause the Oil Price Shock of 2003-2008?” Journal of Forecasting.

Kilian, Lutz, and Thomas Lee, 2013, "Quantifying the Speculative Component in the Real Price of Oil: The Role of Global Oil Inventories," Conference on Understanding International Commodity Price Fluctuations, International Monetary Fund, March.

Kilian, Lutz and D.P. Murphy 2013, "The Role of Inventories and Speculative Trading in the Global Market for Crude Oil," forthcoming: Journal of Applied Econometrics.

Kolb, Robert W. (1992) “Is Normal Backwardation Normal?” Journal of Futures Markets, 12, pp. 75-91.

Kohn, Donald (2008) "The Economic Outlook” speech by the Vice Chairman of the Federal Reserve Board, National Conference on Public Employee Retirement Systems Annual Conference, New Orleans, May 20.

Krugman, Paul (2008a), “Commodity Prices,” New York Times, March 19, at

http://krugman.blogs.nytimes.com/2008/03/19/commodity-prices-wonkish/.

Krugman, Paul (2008b), “The Oil Non-bubble,” New York Times, May 12, http://www.nytimes.com/2008/05/12/opinion/12krugman.html?_r=1

Merino, A. and A. Ortiz (2005), "Explaining the So-called 'Price Premium' in Oil Markets," OPEC Review 29, pp. $133-152$.

Moosa, I. A. and N. E. Al-Loughani (1994), "Unbiasedness and Time Varying Risk Premia in the Crude Oil Futures Market," Energy Economics 16, pp. 99-105.

Phillips, Llad, and John Pippenger (2005), "Some Pitfalls in Testing the Law of One Price in Commodity Markets," University of California at Santa Barbara, Economics Working Paper Series WP 4-05.

Wolf, Martin (2008), “The Market Sets High Oil Prices to Tell us What to Do,” Financial Times, May 13.

Working, Holbrook (1949), “The Theory of Price Storage” American Economic Review, vol. 30, December, pp. 1254-62.

Yang, Jian; David Bessler, and David Leatham (2001), "Asset Storability and Price Discovery in Commodity Futures markets: A New Look," The Journal of Futures Markets. vol. 21(3) March.

Ye, M., J. Zyren, and J. Shore (2002), "Forecasting Crude Oil Spot Price Using OECD Petroleum Inventory Levels," International Advances in Economic Research 8, pp. 324-334.

Ye, M., J. Zyren, and J. Shore (2005), “A Monthly Crude Oil Spot Price Forecasting Model Using Relative Inventories," International Journal of Forecasting 21, pp. 491-501.

Ye, M., J. Zyren, and J. Shore (2006), "Forecasting Short-run Crude Oil Price Using High and Low Inventory Variables," Energy Policy, 34, pp. 2736-2743. 


\section{Appendix I: Data}

\section{Sources:}

\section{A. Commodity Spot and Futures Prices}

Data on commodity spot and futures prices for Copper, Cotton, Corn, Live Hogs, Live Cattle, Oats, Oil, Platinum, Soybeans, Silver and Wheat are from Global Financial Database. To compute real commodity prices, the deflator was the U.S. GDP chain price index taken from the Economic Report of the President 2012. The series are annual and in most cases run from 1950 to 2012.

\section{B. Real Interest Rate}

Annual real interest rate was constructed as the difference between the 3-month U.S. Treasury Bill and the percentage change in the U.S. chain price index. The 3-month U.S. Treasury Bill is from the Economic Report of the President 2012.

C. Inventories

Inventories for commodities are from the Foreign Agricultural Service, U.S. Energy Information Administration, The USDA National Agricultural Statistics Service, and the U.S. Geological Survey. World oil inventories are Observed Oil Inventories: World Total (End of Period, million barrels) .

D. Real World GDP

Annual Real World GDP is measured as World GDP in constant 2000 US\$ from the World Bank's World Development Indicators.

E. Volatility

Volatility was constructed as the standard deviation of monthly commodity spot prices over the past year. Oil's option-implied volatility (for $100 \%$ moneyness level) is from Bloomberg.

F. Spot-Futures Spread

The Spot-Futures Spread is defined as the difference between the futures price and the spot price expressed as percentage of the spot price.

G. GDP, Industrial Production, Inflation and Oil Price Forecasts

Data on Forecasts of U.S. GDP, Industrial Production, Inflation and Oil price were taken from Consensus Economics Inc. Database. The two-year expected IP growth rate is the average of forecasts for current year and subsequent year.

H. Exogenous OPEC Oil Production Shock \& Index of Global Real Economic Activity Monthly and quarterly series were taken from http://www-personal.umich.edu/ lkilian/paperlinks.html 


\section{Real interest rate $1950-2012$}

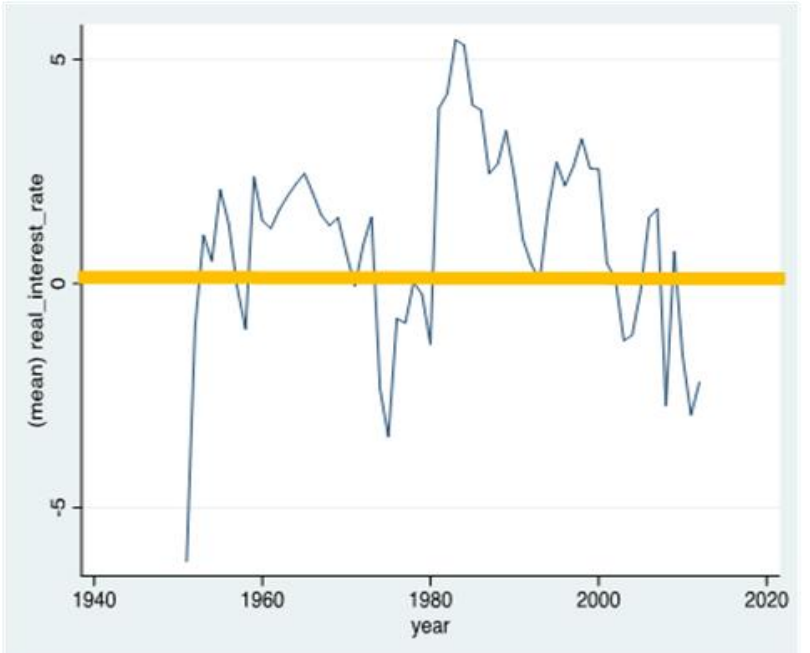

\section{Petroleum inventories}

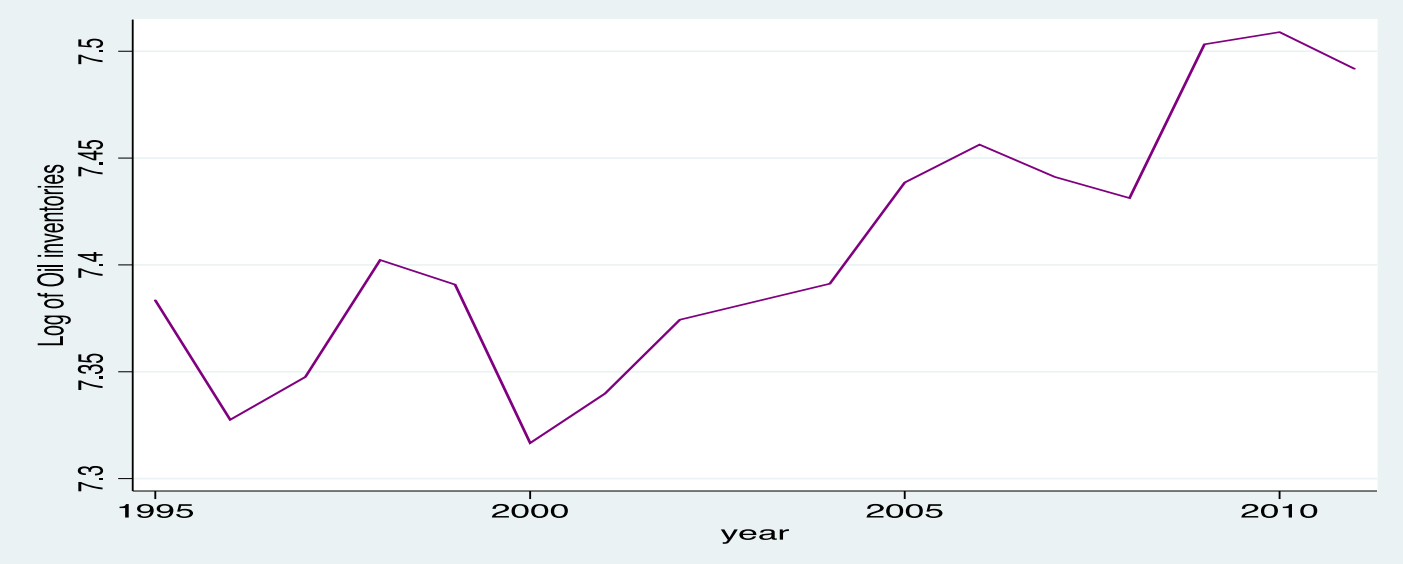

\section{Risk premium}

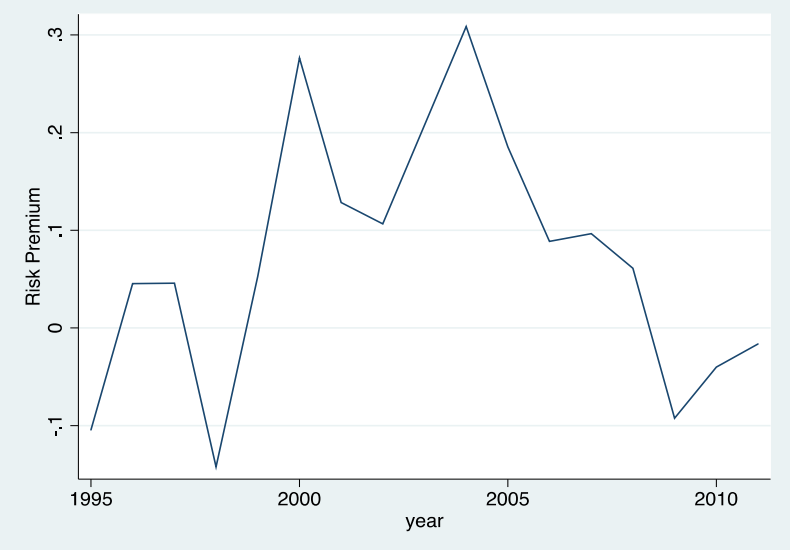

Two measures of volatility: Option-implied and actual volatility






\section{Commodity prices, with future-spot spread}
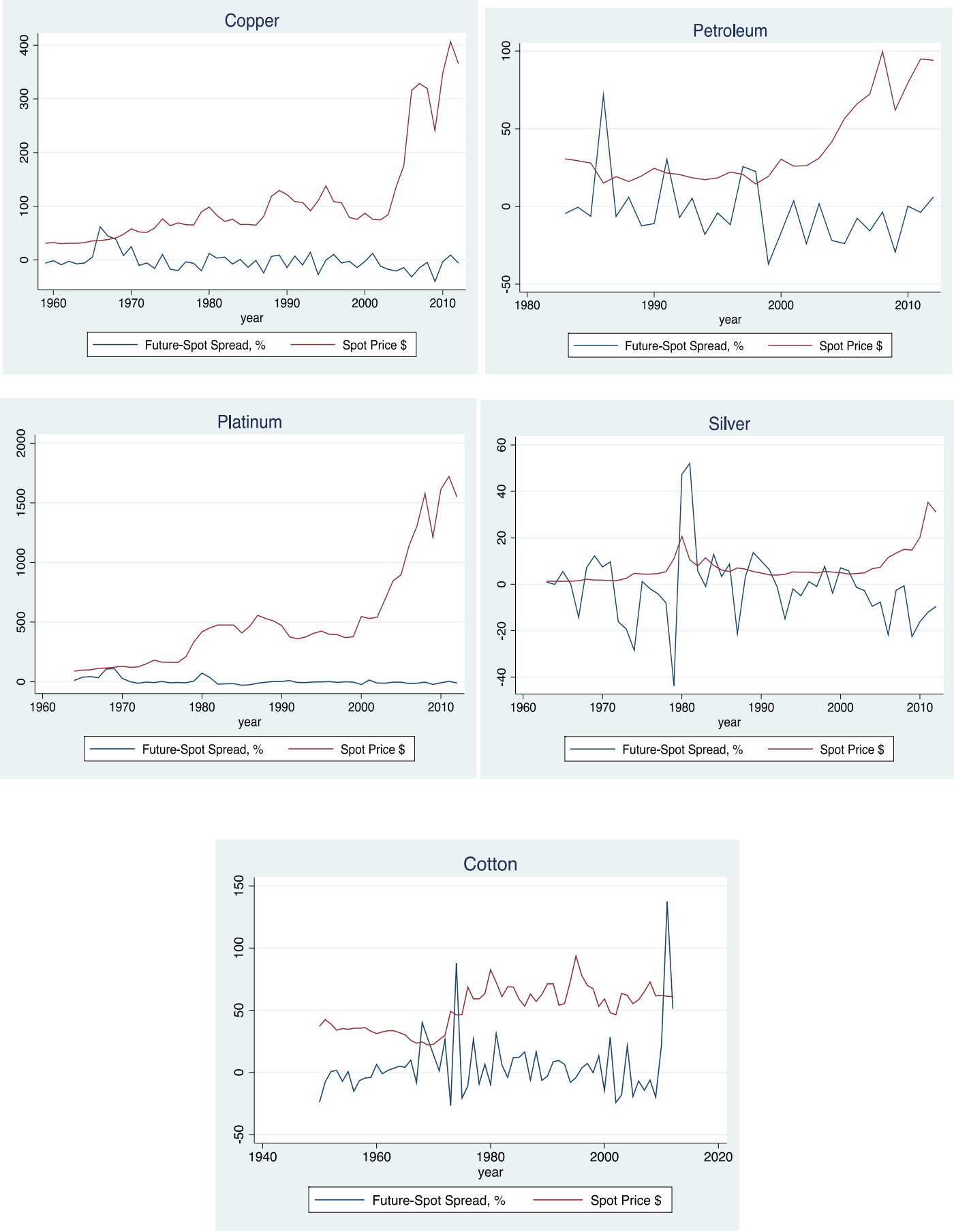

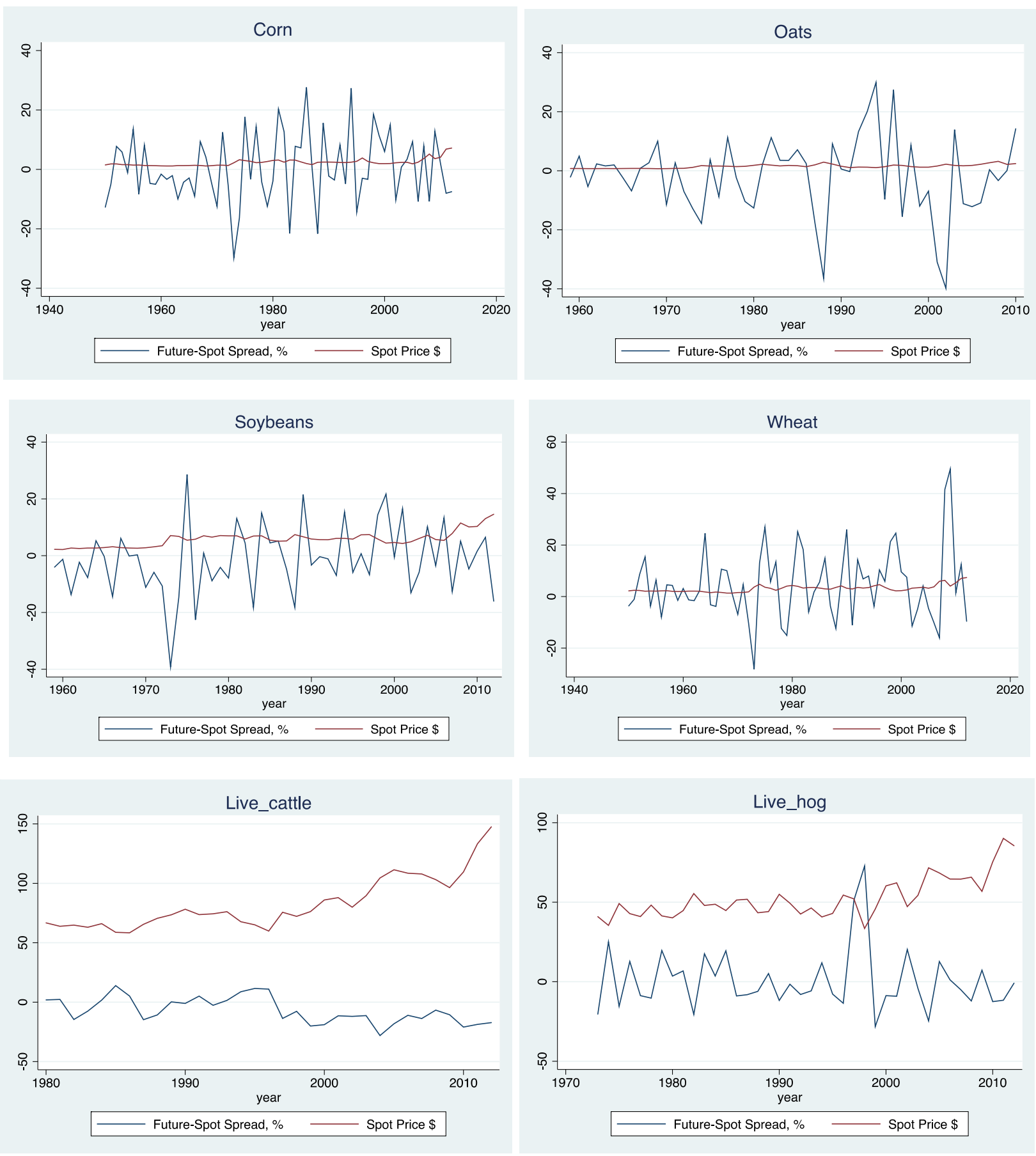